\title{
The Marvel Sonic Narrative: A Study of the Film Music in Marvel's The Avengers, Avengers: Infinity War, and Avengers: Endgame
}

Anthony Walker

West Virginia University, ajw0028@mix.wvu.edu

Follow this and additional works at: https://researchrepository.wvu.edu/etd

Part of the Musicology Commons

\author{
Recommended Citation \\ Walker, Anthony, "The Marvel Sonic Narrative: A Study of the Film Music in Marvel's The Avengers, \\ Avengers: Infinity War, and Avengers: Endgame" (2019). Graduate Theses, Dissertations, and Problem \\ Reports. 7427. \\ https://researchrepository.wvu.edu/etd/7427
}

This Dissertation is protected by copyright and/or related rights. It has been brought to you by the The Research Repository @ WVU with permission from the rights-holder(s). You are free to use this Dissertation in any way that is permitted by the copyright and related rights legislation that applies to your use. For other uses you must obtain permission from the rights-holder(s) directly, unless additional rights are indicated by a Creative Commons license in the record and/ or on the work itself. This Dissertation has been accepted for inclusion in WVU Graduate Theses, Dissertations, and Problem Reports collection by an authorized administrator of The Research Repository @ WVU.

For more information, please contact researchrepository@mail.wvu.edu. 
The Marvel Sonic Narrative:

A Study of the Film Music in

Marvel's The Avengers, Avengers: Infinity War, and Avengers: Endgame

Anthony James Walker

Dissertation submitted to

the College of Creative Arts

at West Virginia University

in partial fulfillment of the requirements for the degree

Doctor of Musical Arts

in Music Performance

Keith Jackson, D.M.A., Chair

Evan A. MacCarthy, Ph.D., Research Advisor

Carson McTeer

Matthew Heap, Ph.D.

Osama Mukdadi, Ph.D.

School of Music

Morgantown, West Virginia

2019

Keywords: Marvel, Avengers, Infinity War, Endgame film music, comic book, comic book movie

Copyright @2019 by Anthony J. Walker

All rights reserved 


\begin{abstract}
The Marvel Sonic Narrative:

A Study of the Film Music in Marvel's The Avengers, Avengers: Infinity War, and Avengers:

Endgame

Anthony James Walker
\end{abstract}

This document explores the music of three films in the Marvel Avengers enterprise: Marvel's The Avengers, Avengers: Infinity War, and Avengers: Endgame. It does not examine the second film of the series, Avengers: Age of Ultron. The document seeks to uncover and further understand the music's function in each film and to determine its continuity throughout all three films. This study uses a combination of film music studies and theory-based analysis to support the findings with the aim of identifying connecting musical elements that stretch throughout these three films. This includes the use of leitmotif/themes, previously introduced music, musical similarity and contrast, as well as ways the music fits in the larger dramatic scheme of each film and the overall function of film music. Ultimately, this document will uncover vital themes that progress the sonic narrative in the Avengers soundscape. 


\section{TABLE OF CONTENTS}

$\begin{array}{lll}\text { Abstract } & \text { ii }\end{array}$

List of Tables $\quad$ iv

The Marvel Cinematic Universe Filmography (2008-2019) V V

$\begin{array}{ll}\text { INTRODUCTION } & 1\end{array}$

CHAPTER ONE

The Music of MARVEL's THE AVENGERS (2012) 5

CHAPTER TWO

The Music of AVENGERS: INFINITY WAR (2018) 17

CHAPTER THREE

The Music of AVENGERS: ENDGAME (2019) 29

$\begin{array}{ll}\text { CONCLUSION } & 40\end{array}$

$\begin{array}{ll}\text { BIBLIOGRAPHY } & 43\end{array}$ 


\section{List of Tables}

Table 1. Cue Sheet for MARVEL'S THE AVENGERS (2012)

Table 2. Cue Sheet for AVENGERS: INFINITY WAR (2018)

Table 3. Cue Sheet for AVENGERS: ENDGAME (2019) 


\section{THE MARVEL CINEMATIC UNIVERSE FILMOGRAPHY}

For the purposes of this document, the Marvel Cinematic Universe (MCU) refers to the universe's live action feature films. It does not include television shows, animated movies, or "One-Shots". It includes films from Paramount Pictures, Universal Pictures, Walt Disney Studios Motion Pictures, and Sony Pictures Releasing, however, only the films that are a part of the shared universe - produced by Kevin Feige. Release dates are listed by U.S. releases.

Iron Man (2008)

\section{Phase One}

The Incredible Hulk (2008)

Iron Man 2 (2010)

Thor (2011)

Captain America: The First Avenger (2011)

Marvel's The Avengers (2012)

Iron Man 3 (2013)

Phase Two

Thor: The Dark World (2013)

Captain America: The Winter Soldier (2014)

Guardians of the Galaxy (2014)

Avengers: Age of Ultron (2015)

Ant-Man (2015)

Captain America: Civil War (2016)

\section{Phase Three}

Doctor Strange (2016)

Guardians of the Galaxy Vol. 2 (2017)

Spider-Man: Homecoming (2017)

Thor: Ragnarok (2017)

Black Panther (2018)

Avengers: Infinity War (2018)

Ant-Man and the Wasp (2018)

Captain Marvel (2019)

Avengers: Endgame (2019)

Spider-Man: Far From Home (2019)

Black Widow (scheduled for 2020)

\section{Phase Four}

The Eternals (scheduled for 2020)

Shang-Chi and the Legend of the Ten Rings (scheduled for 2021)

Doctor Strange in the Multiverse of Madness (scheduled for 2021)

Untitled Spider-Man: Far From Home sequel (scheduled for 2021)

Thor: Love and Thunder (scheduled for 2021)

Black Panther II (scheduled for 2022) 


\section{INTRODUCTION}

Film score study is fairly new in the scheme of music research, and there are glaring gaps in the literature. There has been much research into silent films and westerns, as well as into large franchise films like Jaws, Indiana Jones, Superman, Star Wars (all titles with music by John Williams) ${ }^{1}$, and Lord of the Rings (Howard Shore). ${ }^{2}$ The MCU spans over twenty-plus films (and is still growing), however, aside from film score reviews and critiques, there has not been any substantial research into its music.

Comic book films have grown extremely popular over the past twenty years, to the point that Avengers: Endgame was the highest grossing film of all time. Research into comic book films is somewhat unique in that there is various source material for the films and its scores. For Marvel specifically, there is an eighty-year treasure chest of comics; characters; animated shows and movies; live-action films outside the MCU; and the twenty-two films in the MCU. The films that are the focus of this study could also have possible influences of about fifteen different film scores with different composers.

The nature of film music enables directors and studios to have substantial input on how the music should and will sound. The music takes on a life beyond a composer's control which creates a sonic palette that often stretches across films in the same franchise. This creates a sonic sound for a particular film's universe. One well known example of this type of soundscape is the Star Wars films. The Marvel Cinematic Universe is comprised the same way. ${ }^{3}$

\footnotetext{
${ }^{1}$ Emilio Audissino, John Williams's Film Music: Jaws, Star Wars, Raiders of the Lost Ark, and the Return of the Classical Hollywood Music Style. (Wisconsin Film Studies. Madison, Wisconsin: University of Wisconsin Press, 2014) Accessed September 5, 2019.

${ }^{2}$ Vincent Rone. "Scoring the Familiar and Unfamiliar in Howard Shore's the Lord of the Rings." Music and the Moving Image 11, no. 2 (2018): 37-66.

${ }^{3}$ The MCU was created as part of Marvel Studios, LLC, and is owned by The Walt Disney Company.
} 
The MCU began with the release of Iron Man in 2008. Since then, the MCU spans twentythree films with more on the way. All of the 23 films to date have been co-produced by Kevin Feige and they have had several different directors and composers. All the films and characters are based on Marvel comics, which have been in existence since 1939. Thus, Marvel and the MCU have been around for decades and show no signs of slowing down. This is also true for the "comic book" film craze. Andy Hill has observed:

Certain films have the capacity - in concept, script, in visual realization - to alter the way we see the world.... Everyone who loves cinema has had the experience of leaving a theater with a slightly different walk, talk and attitude, feeling they've carried a bit of the character away with them. ${ }^{4}$

Marvel films are unique, in that, they have a vast eighty-year history, packed with characters and stories that fans have grown to love. They also have the ability to capture new fans, because despite larger-than-life stories and characters, people can always relate to some aspect of their identities or natures.

While printed comics stimulate readers with exquisite visuals and scintillating stories, films have to incorporate additional elements like sound and motion. For sound, this includes both sound effects and screen music. Alan Silvestri (born 1950), the composer for the three films discussed in this study, is a well-established Hollywood composer, having won several awards for his compositions and having composed for over one hundred films, most notably: all three of Robert Zemeckis's Back to the Future films (1985, 1989, and 1990), James Cameron's The Abyss (1989), John McTiernan's Predator (1987), Robert Zemeckis's Forrest Gump (1994), and Steven Spielberg's Ready Player One (2018). In the MCU, he composed the music for Captain America: The First Avenger (2011), Marvel's The Avengers (2012), Avengers: Infinity War (2018), and

\footnotetext{
${ }^{4}$ Andy Hill, Scoring the Screen: The Secret Language of Film Music. Music Pro Guides (Milwaukee, WI: Hal Leonard Books, 2017), 160.
} 
Avengers: Endgame (2019). Furthermore, Silvestri can be accredited with "streamlining" the sound of the universe. While it is unclear whether he worked with some of the later composers, other composers worked off what he created in Marvel's The Avengers, or whether it was a studio decision, elements of Silvestri's music can be heard in many of the films after the 2012 Marvel's The Avengers.

To truly understand the sonic landscape of the $\mathrm{MCU}$, it is important to understand the music of the Avengers films, a series of four films within the broader 23 films. These four films are the combination of all the things that these characters experience, combining character and plot storylines of several more films and creating the climax of an eleven-year narrative, running from 2008 to 2019. As the composer for three of the four films, Silvestri needed to not only lay the groundwork for Danny Elfman (composer for Avengers: Age of Ultron), but he also created a sonic narrative that spanned the music of four films.

This document explores the music of the films in the Avengers enterprise: Marvel's The Avengers, Avengers: Infinity War, and Avengers: Endgame (subsequently referred to as "the three films"). ${ }^{5}$ The study excludes the second film in the series, Avengers: Age of Ultron due to the film having a different composer. Also, the second film is outside the narrative theme that is present throughout the other three films. Films one, three, and four all have a plot on a galactic scale and are centered on storyline's "infinity stones," and more specifically the villain Thanos. The second film, however, has a plot is centered on Midgard (earth), and although there is an infinity stone present in the plot, the villain Thanos is not directly involved in the events of this film.

This study uses a combination of film music studies and theory-based analysis to support the findings with the aim of identifying connecting musical elements that stretch throughout these

\footnotetext{
${ }^{5}$ The soundtracks were recorded by the London Symphony Orchestra.
} 
three films, including the use of leitmotif, new themes that are based on old themes, music introduced later that is used with respect to previously introduced music, musical similarity and contrast, as well as ways the music fits in the larger dramatic scheme of each film, and the overall function of film music. 


\section{CHAPTER ONE}

\section{The Music of MARVEL's THE AVENGERS (2012)}

Loki, brother of Thor, wages war on Midgard (Earth). His ultimate goal is to take control of the Tesseract and harness its power to bring an army (the Chitauri) to subjugate all humanity. In effort to combat Loki's actions, Nick Fury (director of S.H.I.E.L.D.) must call on Earth's mightiest heroes: Iron Man, The Incredible Hulk, Thor, Captain America, Hawkeye and Black Widow. The team must overcome their differences and work together to defeat Loki and his Chitauri forces.

The term leitmotif is most associated with the operas of Richard Wagner, most notably, his cycle of four operas - Der Ring des Nibelungen, in which he represented characters, places, situations, and cyclical ideas with a short musical phrase. ${ }^{6}$ Since Wagner, many composers have utilized leitmotifs, however, it has largely been used in musical spectacles. Over time, this compositional technique found its way into film, where it is utilized in many films (such as: The Abyss, Alan Silvestri; Star Wars series, John Williams; The Lord of the Rings series, Howard Shore; Harry Potter series, John Williams). Like many hero-oriented films, the Avengers films contain many leitmotifs. These motifs or themes can symbolize characters, objects, places, and emotions. These films themes serve different purposes: they reveal when a character has the upperhand in an exchange; foreshadow the direction of the next scene; reinforce what the viewer should be feeling or paying attention to; and in some cases, hint that what the viewer is seeing is not really happening. Themes can be transposed, and they often are, however, the tonal centers of the films

\footnotetext{
${ }^{6}$ Willi Apel, Harvard Dictionary of Music, (Cambridge, Mass: Belknap Press of Harvard University Press, 1979), 467-68. For more information.
} 
are used as expressive tonality. ${ }^{7}$ Expressive tonality occurs when a modulation of a tonal center is used to reinforce what is happening on screen, modulating up to increase the intensity and down to create a sense of relaxation or sadness. Thus, most themes in this document will be presented with the scale degrees and pitches that they first appear in. Each chapter will end with a table; these tables are cue sheets related to each film and are intended to be used in conjunction with this document and the film. The cue sheets can be used to follow along with the film providing a detailed listing of all the music and the presentations of themes. They also provide precise timings of all the themes, where they happen, and what is happening visually.

The first motif that is heard (at 00:13) is what I name the Tesseract theme. This theme later becomes the Infinity Stone theme, but, at the time of this film, the existence of the infinity stones is not yet revealed to the audience. This theme consists of a descending line based in G minor $\hat{3}, \hat{1}, \hat{1}, \# \hat{7}, \# \hat{7}, \hat{7}$ ( $B b, G, G, F \#, F \#, F)$. This theme is heard when the Tesseract is on screen or the center of focus. The next themes introduced are both of Loki's themes. The first theme is an ascending melodic line (E, F\#, F\#, G); this theme is more about the minor motion then the scale degree. Loki's second theme is $\hat{3}, \hat{1}, \hat{3}, \hat{2}$ ( $\mathrm{B} b, \mathrm{G}, \mathrm{B} b, \mathrm{~A})$, this theme is usually present when Loki is doing something more sinister or when the overall feeling is ominous.

For the heroes, many characters have their own themes. The first theme that is presented is Black Widow's theme. This is slightly different from the rest of the team's theme. It has a longer melody and is more exotic with the use of a $b \hat{2}$, the whole theme is in $\mathrm{G}$ minor $\hat{5}, \hat{5}, \hat{4}, \hat{5}, \hat{6}, \hat{1}, \hat{5}, b \hat{2}, \hat{5}, \hat{1}$ (D, D, C, D, Eb, G, D, A $b, \mathrm{D}, \mathrm{G}$ ). The next theme introduced is the Iron Man theme. This theme is similar to Loki's theme in that it is built on a minor third (D, E, F, A,

\footnotetext{
${ }^{7}$ Frank Lehman, Hollywood Harmony: Musical Wonder and the Sound of Cinema. Oxford Music/media Series, (New York, NY: Oxford University Press, 2018), 54-55.
} 
D, E, F). It usually continues to ascend through two octaves. The second aspect that is unique to Iron Man's character is that he is one of the few characters that is tied to diegetic music. ${ }^{8}$ An instance of this is in the scene when Iron Man hacks S.H.I.E.L.D's transport known as the Quinjet, when entering to help Captain America fight Loki. The song is "Shoot to Thrill" by AD/DA, this is the same song he uses in an entrance in Iron Man 2 (2010). ${ }^{9}$ There is also a theme for Tony Stark; it is based on the progression i-VI-v-IV and the melody is the thirds from each chord. Captain America's theme is very similar to the theme introduced in Captain America: The First Avenger (2011; Alan Silvestri was the composer for this film), however, in this film it is heard in minor. The change in his theme signifies that this character has changed; the theme is $\hat{1}, \hat{1}$, low $\hat{5}, \hat{1}, \hat{4}, \hat{3}, \hat{6}(\mathrm{G}, \mathrm{G}, \mathrm{D}, \mathrm{G}, \mathrm{C}, \mathrm{B} b, \mathrm{E} b)$. Thor's theme is (E, G, B, C, G, B), but he also has a second theme that only occurs when he is preparing a "god blast" (Ab, Db, E, F). Finally, Hulk's theme is Gs in octaves, a reference to composer Craig Armstrong's musical theme from The Incredible Hulk (2008), because it only occurs once in the film ${ }^{10}$ (Such cross-film references also serve as cues for viewers).

The last theme is the Avengers theme itself. This theme can be broken down into two parts. The first part is the theme that is introduced when the helicopter flies over the mountains (at 1:19). This part is rhythmically driven by sixteenth notes with two different melodies: first, in minor $\hat{1}, \hat{1}, \hat{2}, \hat{3}, \widehat{4}, \hat{1}$; second, $\hat{5}, \widehat{4}, \hat{3}, \hat{3}, \hat{4}, \hat{5}, \hat{5}, \hat{1}, \hat{5}, \widehat{4}, \hat{3}, \hat{3}, \hat{2}, \hat{1}$. The second part of the theme is first heard at the title screen at (11:39). The theme is only heard in its entirety when the team is fully

\footnotetext{
${ }^{8}$ Diegetic music is music in the film that is part of the setting and can be heard by the characters.

${ }^{9}$ AD/DA's music was also used in Iron Man (2008), however, with a different song "Back In Black"

${ }^{10}$ Christopher Bill, Marvel Music Analysis: Avengers (2012) by Alan Silvestri - Complete Leitmotif Breakdown, 2019. Accessed October 24, 2019. https://youtu.be/k6ubic0mWUE, 18:14. All themes discussed in this paper where derived by Anthony Walker, with the exception of Hulk's theme.
} 
assembled. In this part the rhythm is augmented, eighth notes rather than sixteenths, with a broader melody $\hat{1}, \hat{5}, \hat{4}, \hat{3}, \hat{2}, \hat{1} ; \hat{1}, \hat{5}, \hat{6}, \hat{4}, \hat{5} ; \hat{1}, \hat{5}, \hat{4}, \hat{3}, \hat{2}, \hat{1}, \hat{2}, \hat{1}$.

Outside of all these themes, Silvestri uses tritones throughout the film. ${ }^{11}$ These tritones always signal that something bad is either happening or about to occur. The direction of the tritone often symbolizes the direction of something that is happening. This use of tritones is a similar to a commotional style call word painting - commonly used in vocal music - the music reflects the literal meaning of the text. ${ }^{12}$ Another technique Silvestri uses is the combining of character themes with other music when characters are working together; for the viewer this makes the scene more impactful. It also solidifies the feeling of this being a superhero team film and not just another solo hero film. Furthermore, it reinforces the idea of teamwork; this is shown through how masterfully the full Avengers theme starts once the team is fully assembled.

${ }^{11}$ Tritone is an interval composed of three adjacent whole tones, i.e. an augmented fourth or diminished fifth

12 Apel, Harvard Dictionary of Music, 928. For more information. 
Table 1. Cue Sheet for MARVEL'S THE AVENGERS (2012)

Composer: Alan Silvestri

Director: Joss Whedon

\begin{tabular}{|c|c|c|c|}
\hline Timing & Visual Cue & Music & Notes \\
\hline :02 & Marvel comic strips & Ominous & \\
\hline 13 & the Tesseract & Tesseract theme & $\begin{array}{l}\text { Descending line Full } \\
\text { theme (B } b, \mathrm{G}, \mathrm{G}, \mathrm{F} \#, \mathrm{~F} \text {, } \\
\mathrm{F}) \text {. }\end{array}$ \\
\hline :35 & Up the steps & $\begin{array}{l}\text { Loki theme I } \\
\text { And II }\end{array}$ & $\begin{array}{l}\text { Ascending melodic line } \\
\text { (E, F\#, F\#, G) } \\
(\mathrm{B} b, \mathrm{G}, \mathrm{B} b, \mathrm{~A})\end{array}$ \\
\hline $1: 11$ & $\begin{array}{l}\text { Flash into the } \\
\text { Tesseract }\end{array}$ & $\begin{array}{l}\text { Ascending line } \\
\text { (part of Iron Man theme) }\end{array}$ & $\begin{array}{l}\text { Music question/answer } \\
\text { (Iron Man) }\end{array}$ \\
\hline $1: 19$ & $\begin{array}{l}\text { Helicopter flying } \\
\text { over the mountains }\end{array}$ & Avengers theme I & \\
\hline $2: 03$ & Fury starts talking & Creates a sense of unease & $\begin{array}{l}\text { Descending motion D to } \\
\mathrm{C}\end{array}$ \\
\hline $2: 15$ & $\begin{array}{l}\text { Talking about the } \\
\text { Tesseract }\end{array}$ & Tesseract theme & $\begin{array}{l}\text { Descending motion } \\
\text { continues after }\end{array}$ \\
\hline 3:05 & $\begin{array}{l}\text { Tesseract reacts to } \\
\text { touch }\end{array}$ & Stop & Large section of dialog \\
\hline $3: 42$ & Hawkeye appears & Ascending motion $\mathrm{D}$ to $\mathrm{E} b$ & $\begin{array}{l}1^{\text {st }} \text { avenger, contrary } \\
\text { motion, sense of hope? }\end{array}$ \\
\hline $3: 50$ & $\begin{array}{l}\text { Talking about the } \\
\text { Tesseract }\end{array}$ & Tesseract theme & \\
\hline 4:19 & Tesseract & Stop & The portal is opening \\
\hline $5: 10$ & Loki's face is shown & $\begin{array}{l}\text { Ominous music with Loki } \\
\text { theme II }\end{array}$ & $\begin{array}{l}\text { Descending motion } \\
\mathrm{B} b, \mathrm{G}, \mathrm{B} b, \mathrm{~A}\end{array}$ \\
\hline $5: 35$ & Fighting begins & Stop & \\
\hline $5: 48$ & & $\begin{array}{l}\text { Ominous music extended with } \\
\text { larger orchestration }\end{array}$ & \\
\hline 6:03 & Loki grabs Hawkeye & Stop & \\
\hline $6: 10$ & Loki turns Hawkeye & Ominous & \\
\hline $6: 38$ & $\begin{array}{l}\text { Conversation } \\
\text { between Loki and } \\
\text { Fury }\end{array}$ & $\begin{array}{l}\text { Subtle tension with harmonic } \\
\text { motion }\end{array}$ & $\begin{array}{l}\text { Climaxes at big moments } \\
\text { (turning Selvig) most } \\
\text { "dead space" during } \\
\text { dialog }\end{array}$ \\
\hline 6:59 & End of introduction & i-V-vi-iv-V in D minor & Melody-A, B $b, \mathrm{G}, \mathrm{A}$ \\
\hline $8: 22$ & Barton shots & Chase music & $\begin{array}{l}\text { Musically more active } \\
\text { creating suspense }\end{array}$ \\
\hline $9: 54$ & explosion & Stop & $\begin{array}{l}\text { Builds tension before the } \\
\text { explosion }\end{array}$ \\
\hline
\end{tabular}




\begin{tabular}{|c|c|c|c|}
\hline 10:06 & Ground collapsing & $\begin{array}{l}\text { Similar to the chase music } \\
\text { Without the faster rhythmic } \\
\text { sections }\end{array}$ & $\begin{array}{l}\text { Creates a sense that it } \\
\text { isn't over, however, the } \\
\text { chase has past the climax }\end{array}$ \\
\hline $10: 50$ & $\begin{array}{l}\text { The helicopter is } \\
\text { shot down }\end{array}$ & Stop & \\
\hline 11:09 & $\begin{array}{l}\text { Survivors are } \\
\text { checking each } \\
\text { other's status }\end{array}$ & Creates a sense of defeat & \\
\hline $11: 39$ & Avengers title & Avengers theme II & \\
\hline $11: 49$ & Train & Stop & \\
\hline 12:05 & $\begin{array}{l}\text { Natasha being } \\
\text { questioned }\end{array}$ & $\begin{array}{l}\text { Soft, barely auditable } \\
\text { Black Widow theme }\end{array}$ & $\begin{array}{l}\text { Music is background, } \\
\text { under the dialog } \\
(\mathrm{D}, \mathrm{D}, \mathrm{C}, \mathrm{D}, \mathrm{E} b, \mathrm{G}, \mathrm{D} \text {, } \\
\mathrm{Ab}, \mathrm{D}, \mathrm{G})\end{array}$ \\
\hline $13: 26$ & Phone rings & Stop & \\
\hline $14: 18$ & Fighting starts & Percussion driven & $\begin{array}{l}\text { With the Black Widow } \\
\text { theme }\end{array}$ \\
\hline $14: 55$ & Phone & Stop & \\
\hline $15: 21$ & $\begin{array}{l}\text { Running through the } \\
\text { streets of India }\end{array}$ & $\begin{array}{l}\text { Middle Eastern sounding } \\
\text { create a feeling of being } \\
\text { somewhere else }\end{array}$ & $\begin{array}{l}\text { Change in music with the } \\
\text { location change }\end{array}$ \\
\hline $16: 28$ & Banner & Stop & \\
\hline 18:08 & $\begin{array}{l}\text { Photo of the } \\
\text { Tesseract }\end{array}$ & Tesseract theme & \\
\hline $18: 40$ & Banner hits the table & Stop & \\
\hline $20: 30$ & Captain America & Remembering/longing & $\begin{array}{l}\text { Triumphant sounding but } \\
\text { in minor }\end{array}$ \\
\hline 21:06 & Brakes the bag & Stop & \\
\hline $22: 40$ & $\begin{array}{l}\text { Talking about the } \\
\text { Tesseract }\end{array}$ & Tesseract theme & \\
\hline $23: 20$ & Iron Man & Iron Man theme & Built on minor thirds \\
\hline $24: 15$ & $\begin{array}{l}\text { Tony Stark coming } \\
\text { out of the suit }\end{array}$ & Tony Stark theme & i-VI-v-IV \\
\hline $24: 50$ & Pepper and Tony & Stop & \\
\hline $27: 17$ & $\begin{array}{l}\text { Romantic moment } \\
\text { between Tony and } \\
\text { Pepper Potts }\end{array}$ & Romance- lightens the mood & $\begin{array}{l}\text { Different than anything } \\
\text { previously heard }\end{array}$ \\
\hline $27: 46$ & $\begin{array}{l}\text { Tony grads the } \\
\text { "Tesseract" }\end{array}$ & Stop & \\
\hline 29:17 & $\begin{array}{l}\text { Loki's forces } \\
\text { mobilizing }\end{array}$ & $\begin{array}{l}\text { Ominous music with Loki } \\
\text { theme II }\end{array}$ & \\
\hline $29: 54$ & Loki's projection & Tesseract theme & \\
\hline $31: 30$ & $\begin{array}{l}\text { The Other touches } \\
\text { Loki }\end{array}$ & Stop & \\
\hline $31: 37$ & Helicarrier & Avengers theme I, varied & $\begin{array}{l}\text { The team starts to } \\
\text { assemble }\end{array}$ \\
\hline
\end{tabular}




\begin{tabular}{|c|c|c|c|}
\hline $32: 10$ & $\begin{array}{l}\text { Cap and Natasha } \\
\text { speaking }\end{array}$ & Stop & \\
\hline 33:02 & Helicarrier & $\begin{array}{l}\text { Hopeful theme, elements of the } \\
\text { Avengers theme }\end{array}$ & $\begin{array}{l}\text { Hope for success, } \\
\text { showing all the things at } \\
\text { their disposal }\end{array}$ \\
\hline $34: 55$ & Fury & Stop & \\
\hline $35: 57$ & $\begin{array}{l}\text { Loki's forces } \\
\text { discussing plans }\end{array}$ & $\begin{array}{l}\text { Ominous music with Loki } \\
\text { theme II and theme I }\end{array}$ & \\
\hline $36: 41$ & Back at S.H.I.E.L.D. & Stop & \\
\hline $37: 22$ & Loki at the event & $\begin{array}{l}\text { Schubert-String quartet No. } 13 \\
\text { (Diegetic music) }\end{array}$ & $\begin{array}{l}\text { Both diegetic and not, it } \\
\text { enforces that it is all } \\
\text { happening } \\
\text { simultaneously }\end{array}$ \\
\hline $39: 16$ & $\begin{array}{l}\text { Hawkeye pull out } \\
\text { the iridium }\end{array}$ & Stop & \\
\hline $39: 30$ & $\begin{array}{l}\text { Loki "changes" back } \\
\text { to his normal cloths }\end{array}$ & Builds the tension & $\begin{array}{l}\text { Music tops during car } \\
\text { crash }\end{array}$ \\
\hline 40:07 & Loki yells "kneel" & Stop & \\
\hline 40:20 & Loki's speech & Variation of Loki theme & \\
\hline $40: 50$ & Older man stands up & Music becomes more hopeful & Changing the mood \\
\hline 41:15 & Cap appears & Captain America theme & $\begin{array}{l}\text { Same theme from The } \\
\text { First Avenger but in } \\
\text { minor }(\mathrm{G}, \mathrm{G}, \mathrm{D}, \mathrm{G}, \mathrm{C}, \\
\mathrm{B} b, \mathrm{E} b)\end{array}$ \\
\hline $41: 43$ & $\begin{array}{l}\text { Fight between Loki } \\
\text { and Cap }\end{array}$ & $\begin{array}{l}\text { The music follows the flow of } \\
\text { the fight }\end{array}$ & $\begin{array}{l}\text { Sounding more } \\
\text { triumphant when Cap } \\
\text { seems to be winning and } \\
\text { more sinister with Loki } \\
\text { has the upper hand }\end{array}$ \\
\hline $42: 12$ & Iron Man talking & "Shoot to Thrill" by AD/DA & $\begin{array}{l}\text { same from Iron Man 2, at } \\
\text { the expo } \\
\text { Diegetic music }\end{array}$ \\
\hline $42: 32$ & & Stop & dialog \\
\hline $42: 49$ & $\begin{array}{l}\text { Transporting Loki } \\
\text { on the quinjet }\end{array}$ & Ominous music & $\begin{array}{l}\text { Creating a sense of } \\
\text { unease }\end{array}$ \\
\hline 43:00 & & Stop & dialog \\
\hline $43: 43$ & $\begin{array}{l}\text { Thor lands on the } \\
\text { quinjet }\end{array}$ & $\begin{array}{l}\text { Thor theme/use of the tritone } \\
\text { right before Thor hits Iron Man }\end{array}$ & $\begin{array}{l}1^{\text {st: }}(\mathrm{E}, \mathrm{G}, \mathrm{B}, \mathrm{C}, \mathrm{G}, \mathrm{B}) \\
(\mathrm{E}, \mathrm{B}, \mathrm{C}, \mathrm{B} b) \text { question }\end{array}$ \\
\hline 44:06 & Thor grabs Loki & $\begin{array}{l}\mathrm{D}, \mathrm{E} b, \mathrm{~F}, \mathrm{G}, \mathrm{A} b \text { ascending a } \\
\text { tritone }\end{array}$ & $\begin{array}{l}\text { Represent bad decisions } \\
\text { and increasing tension }\end{array}$ \\
\hline $44: 49$ & Thor drops Loki & Stop & Dialog \\
\hline $46: 22$ & & Loki theme I and II & \\
\hline 47:02 & $\begin{array}{l}\text { Iron Man tackles } \\
\text { Thor }\end{array}$ & Stop & \\
\hline
\end{tabular}




\begin{tabular}{|c|c|c|c|}
\hline 47:49 & $\begin{array}{l}\text { Thor and Iron Man } \\
\text { start fighting }\end{array}$ & $\begin{array}{l}\text { Loki themes transposed and } \\
\text { use of Tritones } \\
\text { Combination of Thor and Iron } \\
\text { Man themes with undertones } \\
\text { of Loki themes }\end{array}$ & $\begin{array}{l}\text { Breaks in the music for } \\
\text { dialog and to increase the } \\
\text { tension } \\
\text { Lots of half step motion }\end{array}$ \\
\hline 49:57 & $\begin{array}{l}\text { Thor hits Cap's } \\
\text { shield }\end{array}$ & Stop & \\
\hline 50:39 & Loki looks at Banner & Loki theme II & \\
\hline 50:54 & Door closes & Stop & \\
\hline $52: 00$ & Fury walking & $\begin{array}{l}\mathrm{G}, \mathrm{A}, \mathrm{B} b, \mathrm{D}, \mathrm{E} b, \mathrm{D} \text { Followed } \\
\text { by Loki theme }\end{array}$ & Loki in control \\
\hline $52: 54$ & Monitor turns off & Stop & Large section of dialog \\
\hline $58: 16$ & $\begin{array}{l}\text { Stark talking about } \\
\text { hacking SHIELD }\end{array}$ & Very low - Loki themes & \\
\hline 58:58 & Cap & Rhythmic pattern & $\begin{array}{l}\text { Represents Cap's mind } \\
\text { turning }\end{array}$ \\
\hline 59:10 & Banner & Stop & \\
\hline 1:00:30 & Banner and Tony & Iron Man theme & \\
\hline $1: 00: 43$ & Cap & Loki theme II & Doing what Loki wants \\
\hline 1:01:15 & $\begin{array}{l}\text { Salvig working with } \\
\text { the Tesseract }\end{array}$ & Tesseract theme & \\
\hline 1:01:30 & Change in location & Stop & \\
\hline 1:02:30 & Thor reminiscing & Solo horn & $\begin{array}{l}\text { Thor putting the weight } \\
\text { on himself }\end{array}$ \\
\hline $1: 02: 54$ & $\begin{array}{l}\text { Talking about what } \\
\text { Loki wants }\end{array}$ & Loki theme I & \\
\hline 1:03:40 & $\begin{array}{l}\text { Loki talking to } \\
\text { Black Widow }\end{array}$ & Stop & \\
\hline 1:04:33 & $\begin{array}{l}\text { Black Widow sits } \\
\text { down }\end{array}$ & $\begin{array}{l}\text { Black Widow theme and Loki } \\
\text { themes playing against each } \\
\text { other }\end{array}$ & $\begin{array}{l}\text { The shifting themes } \\
\text { represent a "fight" with } \\
\text { words...the God of } \\
\text { mischief vs the spy }\end{array}$ \\
\hline $1: 06: 23$ & Loki's threats & $\begin{array}{l}\text { Long crescendo with rising } \\
\text { glis }\end{array}$ & \\
\hline 1:06:48 & Widow looks up & Stop & The spy won \\
\hline 1:06:54 & Talking on the radio & $\begin{array}{l}\text { Hopeful theme twisted and in } \\
\text { minor } \\
\text { Mixing Loki theme }\end{array}$ & $\begin{array}{l}\text { Stops or gets quiet for } \\
\text { dialog...stop for } \\
\text { dramatic pause, } \\
\text { decreased volume to } \\
\text { increase the tension }\end{array}$ \\
\hline $1: 12: 35$ & $\begin{array}{l}\text { Hawkeye Blows one } \\
\text { of the engines } \\
\text { Hawkeye's (Loki) } \\
\text { team moving }\end{array}$ & $\begin{array}{l}\text { Action music } \\
\text { Ascending lines to create a } \\
\text { sense of angst } \\
\text { Lots of dissonance } \\
\text { Thor theme varied }\end{array}$ & $\begin{array}{l}\text { Melodic line } \mathrm{C}, \mathrm{G}, \mathrm{A} b, \\
\mathrm{D} b \\
\text { Hints at tritones }\end{array}$ \\
\hline
\end{tabular}




\begin{tabular}{|c|c|c|c|}
\hline 1:14:06 & $\begin{array}{l}\text { Widow talking to } \\
\text { Banner/Hulk }\end{array}$ & Stop & \\
\hline $1: 14: 44$ & $\begin{array}{l}\text { Bruce turns into } \\
\text { Hulk }\end{array}$ & Sadness & $\mathrm{D}, \mathrm{B} b, \mathrm{C}, \mathrm{A}$ \\
\hline 1:15:07 & Widow vs Hulk & $\begin{array}{l}\text { Chase music } \\
\text { Tritones and half steps }\end{array}$ & $\begin{array}{l}\text { Ab, A, D } \\
\text { Stops when the on } \\
\text { Loki's face }\end{array}$ \\
\hline $1: 15: 26$ & Fury giving orders & Rhythmic focus, no melodies & \\
\hline $1: 15: 45$ & $\begin{array}{l}\text { Cap and Iron Man } \\
\text { working on the } \\
\text { engine }\end{array}$ & $\begin{array}{l}\text { Start with Avengers theme II } \\
\text { Mixes Cap theme and Iron } \\
\text { Man theme }\end{array}$ & \\
\hline $1: 16: 32$ & Widow vs Hulk & Stop & \\
\hline $1: 16: 52$ & $\begin{array}{l}\text { Hulk chasing } \\
\text { Widow }\end{array}$ & $\begin{array}{l}\text { Chase music Heavy horns } \\
\text { Tritones and half steps }\end{array}$ & \\
\hline 1:17:06 & Hulk hits Widow & Stop & $\begin{array}{l}\text { Some dissonance on F } \\
\text { (F\# sus resolving to F) } \\
\text { builds the tension before } \\
\text { Thor saves Widow }\end{array}$ \\
\hline 1:17:19 & Hulk vs Thor & Crescendos and glisses & (D\# sus resolving to $\mathrm{D}$ ) \\
\hline $1: 17: 44$ & Cap and Iron Man & $\begin{array}{l}\text { Mixes Cap theme and Iron } \\
\text { Man theme }\end{array}$ & \\
\hline $1: 18: 16$ & Hulk vs Thor & Rhythmic focus & \\
\hline 1:19:05 & Fury & $\begin{array}{l}\text { Rhythmic focus with } \\
\text { dissonance }\end{array}$ & \\
\hline $1: 19: 34$ & Hulk vs Thor & $\begin{array}{l}\text { Rhythmic focus with } \\
\text { dissonance }\end{array}$ & \\
\hline 1:19:39 & Fury & $\begin{array}{l}\text { Rhythmic focus with } \\
\text { dissonance }\end{array}$ & \\
\hline $1: 20: 49$ & Cap and Iron Man & $\begin{array}{l}\text { Mixes Cap theme and Iron } \\
\text { Man theme }\end{array}$ & \\
\hline $1: 21: 34$ & Fury & Tritones & \\
\hline $1: 22: 26$ & Cap and Iron Man & Cap/Iron Man theme & \\
\hline $1: 22: 55$ & Thor vs Loki & Stop & Mostly dialog \\
\hline $1: 23: 18$ & Hawkeye vs Widow & Percussive music & \\
\hline $1: 23: 43$ & Thor vs Loki & Stop & Mostly dialog \\
\hline $1: 24: 30$ & $\begin{array}{l}\text { Loki points at the } \\
\text { blood }\end{array}$ & Ominous music & \\
\hline $1: 24: 52$ & Thor falls & Stop & \\
\hline $1: 25: 00$ & Hawkeye vs Widow & Percussive music & \\
\hline $1: 25: 19$ & Widow wins & Stop & \\
\hline $1: 26: 33$ & Fury & Rhythmically active & \\
\hline $1: 26: 47$ & Cap and Iron Man & Cap/Iron Man theme & \\
\hline $1: 27: 21$ & $\begin{array}{l}\text { Iron Man hit the } \\
\text { blade }\end{array}$ & Stop & \\
\hline
\end{tabular}




\begin{tabular}{|c|c|c|c|}
\hline $1: 27: 33$ & $\begin{array}{l}\text { Iron Man starts } \\
\text { flying }\end{array}$ & Cap/Iron Man theme & \\
\hline $1: 27: 46$ & Loki escapes & Loki theme II & \\
\hline $1: 27: 56$ & $\begin{array}{l}\text { Fury talking to } \\
\text { Colson }\end{array}$ & Stop & \\
\hline $1: 28: 30$ & Colson dies & High strings - longing & \\
\hline 1:31:04 & Thor & Stop & \\
\hline $1: 34: 44$ & Nat and Barton & Black Widow theme & \\
\hline $1: 35: 17$ & $\begin{array}{l}\text { Cap and Iron Man } \\
\text { talking }\end{array}$ & Stop & \\
\hline $1: 36: 15$ & $\begin{array}{l}\text { Tony and Cap } \\
\text { talking }\end{array}$ & $\begin{array}{l}\text { Loki theme and Iron Man } \\
\text { theme }\end{array}$ & \\
\hline $1: 37: 10$ & Thor & Avengers theme variation & \\
\hline 1:39:11 & Iron Man lands & Loki and Iron Man themes & \\
\hline 1:39:50 & Loki & Stop & \\
\hline $1: 40: 35$ & Tony & Loki and Iron Man themes & very quiet \\
\hline $1: 41: 10$ & $\begin{array}{l}\text { Scepter touches } \\
\text { Tony reactor }\end{array}$ & Stop & \\
\hline $1: 41: 41$ & $\begin{array}{l}\text { Suit breaks the } \\
\text { window }\end{array}$ & Iron Man theme II & \\
\hline 1:42:10 & Iron Man shot Loki & Stop & \\
\hline $1: 42: 24$ & Long fight scene & $\begin{array}{l}\text { fight music } \\
\text { Very active, combines } \\
\text { previous themes }\end{array}$ & $\begin{array}{l}\text { Pauses to add the drama } \\
\text { Use of tritones } \\
\text { Changing textures and } \\
\text { feels depending on who's } \\
\text { on screen }\end{array}$ \\
\hline $1: 50: 44$ & Banner pulls up & Stop & \\
\hline $1: 51: 25$ & $\begin{array}{l}\text { The Avengers fully } \\
\text { assemble }\end{array}$ & Full Avengers theme II & \\
\hline $1: 53: 32$ & $\begin{array}{l}\text { Thor conjuring } \\
\text { lightning }\end{array}$ & preparing a god blast & $\mathrm{A} b, \mathrm{Db}, \mathrm{E}, \mathrm{F}$ \\
\hline 1:55:09 & Hulk & Hulk theme & Octave Gs \\
\hline 1:56:08 & Black Widow & Black Widow theme & \\
\hline $1: 56: 41$ & $\begin{array}{l}\text { Large section of } \\
\text { teamwork }\end{array}$ & Avengers theme II & \\
\hline $1: 57: 18$ & $\begin{array}{l}\text { Chitauri Leviathan } \\
\text { crashes }\end{array}$ & Stop & \\
\hline $1: 57: 32$ & Salvig & Ominous musical question & $\begin{array}{l}\mathrm{B} b, \mathrm{G}, \mathrm{G}, \mathrm{G} b \\
\text { Similar the Tesseract } \\
\text { theme/Salvig wondering } \\
\text { "What have I done?" }\end{array}$ \\
\hline $1: 57: 50$ & Mirror & Cap theme & \\
\hline 1:58:37 & The people & Empty/without hope & $\begin{array}{l}\text { Wondering if they can } \\
\text { win }\end{array}$ \\
\hline
\end{tabular}




\begin{tabular}{|l|l|l|l|}
\hline 1:59:20 & Widow & fight music & \\
\hline $2: 00: 09$ & Loki's speech & Loki Theme II & \\
\hline $2: 00: 14$ & $\begin{array}{l}\text { Interrupted but the } \\
\text { Hulk }\end{array}$ & Stop & Tesseract theme \\
\hline $2: 00: 54$ & Thor and Iron Man & $\begin{array}{l}\text { fight music and Iron Man } \\
\text { theme }\end{array}$ & \\
\hline $2: 02: 05$ & $\begin{array}{l}\text { The team becomes } \\
\text { overwhelmed }\end{array}$ & Solemn Music & \\
\hline 2:04:50 & Iron Man & Rhythmically active & \\
\hline $2: 06: 03$ & $\begin{array}{l}\text { Nuke through the } \\
\text { portal }\end{array}$ & Stop & Dramatic effect \\
\hline $2: 06: 06$ & Agent Hill & Solemn Music & Dramatic effect \\
\hline $2: 07: 00$ & $\begin{array}{l}\text { Stops right before } \\
\text { Cap says close it }\end{array}$ & Stop & \\
\hline $2: 07: 35$ & Iron Man is falling & $\begin{array}{l}\text { Solemn until Hulk catches } \\
\text { him, then triumphant }\end{array}$ & \\
\hline $2: 08: 13$ & Hulk yells & Stop & Dialog \\
\hline $2: 09: 02$ & $\begin{array}{l}\text { The team in front of } \\
\text { Loki }\end{array}$ & Avengers theme II & \\
\hline $2: 09: 36$ & $\begin{array}{l}\text { People talking about } \\
\text { the Avengers }\end{array}$ & Grateful & \\
\hline $2: 10: 45$ & $\begin{array}{l}\text { Fury talking to the } \\
\text { council }\end{array}$ & $\begin{array}{l}\text { Tesseract theme/Avengers } \\
\text { theme }\end{array}$ & \\
\hline $2: 12: 33$ & Stark and & Avengers theme II & \\
\hline $2: 13: 03$ & Credits & Avengers Theme I and II & \\
\hline $2: 15: 00$ & Space & Stop & \\
\hline $2: 15: 42$ & Thanos & & \\
\hline & & & \\
\hline
\end{tabular}

The use of thematic material in this film helps viewers to follow and understand the narrative of the film. Each character (with the exception of Hawkeye) is introduced with his or her respective theme. As the characters grow more dependent on each other, the themes become less pronounced. Silvestri also begins combining themes to reinforce the concept of teamwork (see 1:17:44). This scene where Captain America and Iron Man are working together to repair the Helicarrier is the first scene were the heroes stop acting as individuals and began working as a team. Once the team is fully assembled, Silvestri virtually abandons character themes, only using them in moments were a hero was doing something that only they could: Thor preparing a "god 
blast" (1:53:32); Hulk smashing the biggest "bad guy" (1:55:09); Black Widow "infiltrating" the enemy (1:56:08); and Captain America's persistence (1:57:50). These short recalls of the theme reminds the viewers that each member of the team is unique. 


\section{CHAPTER TWO \\ The Music of AVENGERS: INFINITY WAR (2018)}

Immediately after the destruction of Asgard, the mad titan Thanos - already possessing the power stone - and his Children (The Black Order - Proxima Midnight, Ebony Maw, Corvus Glaive and Cull Obsidian) begin their hunt for the Infinity Stones. While traveling across the cosmos, the fractured Avengers must overcome the events of Captain America: Civil War while bolstering their ranks with allies such as Dr. Strange, Spider-Man, Black Panther, and the Guardians of the Galaxy to try and stop Thanos in his goal to wipeout half of all existence. As stated previously, this document will not discuss the second film, Avengers: Age of Ultron, because it is outside the narrative theme that is present throughout the other three films.

Avengers: Infinity War is a distinctive film and soundtrack. What makes this film so different is that the heroes are not the protagonists. This film centers on Thanos's journey to overcome the Avengers to bring about his ultimate goal of the "salvation" of the universe. Understanding this plot point is crucial in understanding the music. Furthermore, like Marvel's The Avengers, much of this music in is set in minor tonality, which can make "good and bad" somewhat ambiguous. This directly contradicts most people's impressions on how film music should sound. "The hero swoops in to the sound of a brash major fanfare...A screechingly dissonant stinger announces the arrival of the villain...A bold modulation hurtles across tonal space, just as the camera pans over a fantastic new landscape."13 Silvestri takes a "newer" approach. Much like Hans Zimmer's soundtracks for the Dark Knight film trilogy (2005, 2008, 2012), the themes are more about world building than "good and bad." Sonic world building is a

\footnotetext{
${ }^{13}$ Frank Lehman, Hollywood Harmony: Musical Wonder and the Sound of Cinema. Oxford Music/media Series, (New York, NY: Oxford University Press, 2018), 15.
} 
common goal of most fantasy film composers. Much like the visual building of a world, sonic world building is creating a structual sound that is closely aligned with the world at large. By doing so, viewers are "transported" to this new world and are more likely to suspend belief.

Starting with Thanos, the film starts with a vi - i (Eb minor to $\mathrm{G}$ minor), with half step contrary motion $\mathrm{E} b$ to $\mathrm{D}$ and F\# to G. This is Thanos's first theme, and it can be heard anytime a character is discussing him or when he is on screen. His second theme is only heard once. It occurs when he places the space stone in the gauntlet $\mathrm{B}, \mathrm{B} b, \mathrm{~B}, \mathrm{D} b, \mathrm{~B}, \mathrm{G}, \mathrm{D}, \mathrm{E} b, \mathrm{~A} b, \mathrm{~B} b, \mathrm{~B}, \mathrm{D} b, \mathrm{D}$. Although this theme is only heard once, it is extremely important. The music in this whole scene is contradictory to the concept of superhero soundtracks. This section begins when Ebony Maw presents Thanos with the Tesseract (i.e. Space stone). Here, the viewer is presented with a beautiful melody in the high string. When Thanos puts the stone in the gauntlet, Thanos's theme II is sweepingly triumphant, not doom and gloom. This is the first hint that give insight into whose journey this film is about. The next piece of music pertaining to Thanos is the Thanos "just" motif. Thanos believes he is on a noble quest to save the universe before it destroys itself because he believes the ends justify the means, so he will do whatever is possible. The motif that coincides with this ideology can be heard at about (1:05:57). The motif is in $\mathrm{D} b$ minor $\hat{5}, \hat{6}, \hat{1}, \hat{5}$ (A, $\mathrm{A} b, \mathrm{D} b$, $\mathrm{A} b$ ). The impactful aspect about this theme is it can be heard when Gamora is talking about Thanos and his actions, however it is through her eyes, so the theme is changed and contains tritones $(\mathrm{B} b$, $\mathrm{A}, \mathrm{E} b, \mathrm{~A})$. The use of the tritone makes the motif sound more menacing. Contrasting, through Thanos's eyes, the tritones become a perfect fourth; this is also another instance of Silvestri using expressive tonality. The motif is transposed down a half-step creating a sense of relaxation and piece, while the perfect fourth creates sense of contentment. After all these themes, if viewers are still not convinced that this film is about Thanos's journey, Silvestri spells it out plainly with the 
music after "the snap". When Thanos gets to "The Garden", the music that is presented is triumphant and serene; it is one of the largest melodic sections in the film. The section ends with a smile on Thanos's face 4-3 sus Picardy third ${ }^{14}$ in G, signifying a happy ending for Thanos.

The next big theme present in this film is the magic theme, $\hat{1}, \hat{2}, b \hat{6}$ or $\hat{1}, b \hat{2}, b \hat{6}$ or $\hat{2}, \hat{1}, b \hat{6}$ or $b \hat{2}, \hat{1}, b \hat{6}$. The presence of these intervals were used when there was something "supernatural" occurring (i.g. magic, mind reading, Spidey senses, or sometimes even infinity stones). A few examples of this theme are: Ebony Maw using magic to bind Thor, Spider-Man's Spidey senses on the bus, and Mantis reading Thor's emotions. The most crucial use of this theme, however, comes in the scene where the Guardians go to Knowhere to defeat Thanos. When the team is watching Thanos question the Collector, this theme can be heard right before Thanos steps on him. The presence of this theme is actually meant to alert the viewer that this is not real.

The last theme introduced in this film is the sacrifice theme. It can be heard twice: when Thanos sacrifices Gamora to get the soul stone and when Scarlet Witch sacrifices Vision to prevent Thanos from getting the mind stone. The theme is the same both times, showing that both characters truly believed there was no other way to achieve their goal (getting all the stones or preventing him from obtaining them). It also shows that although many believe Thanos to be a "monster", he sincerely loved Gamora, even as much as Scarlet Witch loved Vision. This theme is in $\mathrm{G}$ minor: $\mathbf{B} \boldsymbol{b}, \mathrm{A}, \mathrm{C}, \mathrm{A}$, then $\mathbf{G}, \mathrm{A}, \mathrm{B} b, \mathrm{~B} b, \mathrm{G}, \mathbf{C}, \mathrm{A}$, then $\mathbf{E}, \mathrm{D}, \mathrm{C}, \mathbf{B}$, then $\mathbf{B}, \mathrm{E} b, \mathrm{~A} b, \mathrm{~B} b, \mathrm{~B}$, $\mathrm{A} b, \mathbf{B}, \mathrm{B} b{ }^{15}$

\footnotetext{
${ }^{14}$ Picardy third is when a musical section ends with a major chord of the tonic, while the preceding music is either modal or in a minor key.

${ }^{15}$ The chord changes are marked by bold note names and the chords progression is: pedal G, Gm, C/G, Am, GM, $\mathrm{A} b \mathrm{~m}, \mathrm{E} b \mathrm{~m} \mathrm{sus}^{6-5}$
} 
Table 2. Cue Sheet for AVENGERS: INFINITY WAR (2018)

Composer: Alan Silvestri

Directors: Anthony and Joseph Russo

\begin{tabular}{|c|c|c|c|}
\hline Timing & Visual Cue & Music & Notes \\
\hline$: 15$ & Comic strips & Thanos theme I & $\begin{array}{l}\mathrm{vi}-\mathrm{i} \text {, half step motion } \\
\mathrm{E} b \text { minor to } \mathrm{G} \text { minor }\end{array}$ \\
\hline 3:03 & $\begin{array}{l}\text { Thanos gives Loki a } \\
\text { choice }\end{array}$ & Eerie, creating tension & \\
\hline $3: 33$ & Loki, "Stop" & Stop & \\
\hline $3: 44$ & $\begin{array}{l}\text { Loki revise the } \\
\text { Tesseract }\end{array}$ & $\begin{array}{l}\text { Embellished Loki theme II } \\
\text { (from Avengers) }\end{array}$ & $\begin{array}{l}\mathrm{B} b, \mathrm{G}, \mathrm{B} b, \mathrm{~A} \\
\text { Use of downward tritone } \\
\text { preceding } \mathrm{D}, \mathrm{E} b, \mathrm{~A}\end{array}$ \\
\hline $4: 15$ & Hulk vs Thanos & $\begin{array}{l}\text { Fight music, full of action } \\
\text { Thanos theme I }\end{array}$ & $\begin{array}{l}\text { The mood of the music } \\
\text { flows the battle, } \\
\text { Hulk-trumpets } \\
\text { Thanos-low brass }\end{array}$ \\
\hline $5: 11$ & $\begin{array}{l}\text { Ebony Maw using } \\
\text { magic }\end{array}$ & Magic theme & $\begin{array}{l}\hat{1}, \hat{2}, b \hat{6} \\
\mathrm{D}, \mathrm{E}, \mathrm{B} b\end{array}$ \\
\hline $5: 20$ & Heimdall praying & Dramatic, Heimdall theme & $\mathrm{A}, \mathrm{A} b, \mathrm{G} b, \mathrm{~F}$ \\
\hline $5: 34$ & & Stop & \\
\hline 5:39 & $\begin{array}{l}\text { Thanos looking at } \\
\text { Heimdall }\end{array}$ & $\begin{array}{l}\text { Dark, preceding something } \\
\text { "bad" } \\
\text { Thanos theme I }\end{array}$ & $\mathrm{G}, \mathrm{A}, \mathrm{B} b$ \\
\hline $5: 50$ & $\begin{array}{l}\text { Thanos kill } \\
\text { Heimdall }\end{array}$ & Sorrowful & \\
\hline 6:07 & $\begin{array}{l}\text { Maw cover Thor's } \\
\text { mouth }\end{array}$ & Magic theme & $\hat{1}, \hat{2}, b \hat{6}$ \\
\hline $6: 15$ & $\begin{array}{l}\text { Maw presenting } \\
\text { Thanos with the } \\
\text { Tesseract }\end{array}$ & $\begin{array}{l}\text { Minor thirds, with a hit of } \\
\text { beauty, high strings }\end{array}$ & $\begin{array}{l}\text { Hinting at Thanos's } \\
\text { "dark" victory not just in } \\
\text { the moment? Harp }\end{array}$ \\
\hline 7:06 & Stone drops & Thanos theme II & $\begin{array}{l}\mathrm{B}, \mathrm{B} b, \mathrm{~B}, \mathrm{D} b, \mathrm{~B}, \mathrm{G}, \mathrm{D}, \\
\mathrm{E} b, \mathrm{~A} b, \mathrm{Bb}, \mathrm{B}, \mathrm{D} b, \mathrm{D}\end{array}$ \\
\hline $7: 33$ & Loki & Stop & Dialog \\
\hline 8:00 & Loki's introduction & $\begin{array}{l}\text { i-V-vi-iv-V in G minor (quote } \\
\text { from } 1^{\text {st }} \text { movie) }\end{array}$ & Melody-D, E $b, \mathrm{C}, \mathrm{D}$ \\
\hline $8: 24$ & Thanos vs Loki & $\begin{array}{l}\text { Half steps and thirds, creating } \\
\text { a sense of unease }\end{array}$ & \\
\hline $9: 15$ & $\begin{array}{l}\text { Thor's mouth is } \\
\text { covered }\end{array}$ & Sorrowful & \\
\hline $9: 40$ & Thanos uses a stone & Large and dramatic & $\begin{array}{l}\text { Show the scale of } \\
\text { Thanos's power with the } \\
\text { stones }\end{array}$ \\
\hline
\end{tabular}




\begin{tabular}{|c|c|c|c|}
\hline 10:07 & $\begin{array}{l}\text { Panning out from the } \\
\text { ships }\end{array}$ & $\begin{array}{l}\text { A final Loki theme I } \\
\text { Broad symbolizing Loki is } \\
\text { dead }\end{array}$ & $\mathrm{B} b, \mathrm{C}, \mathrm{C}, \mathrm{D} b$ \\
\hline 10:16 & $\begin{array}{l}\text { Hulk traveling } \\
\text { through the Bifröst }\end{array}$ & Avengers theme I & $\begin{array}{l}\text { Theme is a mix of the } \\
\text { original and Danny } \\
\text { Elfman's take. } \\
\text { Giving a sense that the } \\
\text { characters have grown }\end{array}$ \\
\hline $10: 40$ & Wang & Stop & \\
\hline 11:09 & $\begin{array}{l}\text { "Thanos is } \\
\text { coming"/Title screen }\end{array}$ & Avengers theme II & $\begin{array}{l}\text { Theme is a mix of the } \\
\text { original and Danny } \\
\text { Elfman's take. }\end{array}$ \\
\hline $11: 29$ & The city & Stop & \\
\hline $12: 10$ & $\begin{array}{l}\text { Tony talking about a } \\
\text { bright future }\end{array}$ & Avengers theme variation & Hopeful sounding \\
\hline $12: 50$ & $\begin{array}{l}\text { Dr. Strange “Tony } \\
\text { Stark” }\end{array}$ & Stop & Dialog \\
\hline 13:03 & "We need your help" & Tension & \\
\hline 13:09 & $\begin{array}{l}\text { Bruce walks through } \\
\text { the portal }\end{array}$ & & $\mathrm{D}, \mathrm{C}, \mathrm{D} b$ \\
\hline $13: 25$ & $\begin{array}{l}\text { Wong explaining the } \\
\text { infinity stones origin }\end{array}$ & Infinity stones theme & Was the Tesseract theme \\
\hline 14:00 & $\begin{array}{l}\text { Eye of Agamotto } \\
\text { opens }\end{array}$ & Stop & \\
\hline 14:08 & "Thanos" & Thanos theme I & \\
\hline $14: 33$ & & Stop & Dialog \\
\hline $15: 50$ & Talking about Cap & Reminiscence & $\begin{array}{l}\text { Use of tritones to signal } \\
\text { how bad it is }\end{array}$ \\
\hline $16: 51$ & Cell phone & Stop & \\
\hline $18: 15$ & Parker's hair moves & Magic theme & $\begin{array}{l}\hat{1}, b \hat{2}, b \hat{6} \\
\text { Spidey senses }\end{array}$ \\
\hline 18:21 & $\begin{array}{l}\text { Spider-Man getting } \\
\text { ready }\end{array}$ & $\begin{array}{l}\text { Spider-Man theme or } \\
\text { Avengers theme variation }\end{array}$ & \\
\hline $18: 58$ & Tony & Stop & \\
\hline 19:05 & Dr. Strange & $\begin{array}{l}\text { Strong Chords } \\
\text { Dm, D\#m, Em }\end{array}$ & $\begin{array}{l}\text { Showing the scale of his } \\
\text { power }\end{array}$ \\
\hline 19:14 & Tony looks back & Stop & \\
\hline $19: 24$ & $\begin{array}{l}\text { Part of the black } \\
\text { order }\end{array}$ & Ominous & \\
\hline 19:58 & $\begin{array}{l}\text { Dr. Strange ready } \\
\text { for a fight }\end{array}$ & $\begin{array}{l}\text { Music livens still with empty } \\
\text { space, creating a sense of angst }\end{array}$ & $\begin{array}{l}\text { Ends with a heavy tritone } \\
\text { motion, basically saying } \\
\text { something bad is about to } \\
\text { happen }(\mathrm{A} b, \mathrm{D}, \mathrm{D} b, \mathrm{C})\end{array}$ \\
\hline $20: 20$ & Stark and Banner & Avengers theme II & \\
\hline
\end{tabular}




\begin{tabular}{|c|c|c|c|}
\hline $21: 17$ & $\begin{array}{l}\text { Black order vs } \\
\text { Avengers }\end{array}$ & $\begin{array}{l}\text { Pulsating, } \\
\text { Becomes more active when } \\
\text { Iron Man fights Cull Obsidian, } \\
\text { Stopping for big moments, } \\
\text { elements of the Avengers } \\
\text { theme }\end{array}$ & $\begin{array}{l}\text { Creates a sense that his is } \\
\text { a different kind of fight, } \\
\text { not about brute } \\
\text { strength... also doesn't } \\
\text { favor either side in the } \\
\text { beginning, however, } \\
\text { begins to as the fight } \\
\text { progresses }\end{array}$ \\
\hline $24: 33$ & $\begin{array}{l}\text { Cull Obsidian falls } \\
\text { through portal }\end{array}$ & Stop & \\
\hline $24: 49$ & Iron Man takes off & Continues & Mostly heroic \\
\hline $25: 54$ & $\begin{array}{l}\text { Iron Man is in the } \\
\text { ship }\end{array}$ & Stop & \\
\hline $26: 38$ & $\begin{array}{l}\text { Spidey is still on the } \\
\text { ship }\end{array}$ & Continues & \\
\hline $26: 57$ & $\begin{array}{l}\text { Banner picks up the } \\
\text { phone }\end{array}$ & Stop & \\
\hline $27: 18$ & $\begin{array}{l}\text { Steve Rogers } \\
\text { number }\end{array}$ & $\begin{array}{l}\text { "Rubber band Man" by the } \\
\text { Spinners } \\
\text { Diegetic music }\end{array}$ & $\begin{array}{l}\text { Hinting to where the next } \\
\text { scene is }\end{array}$ \\
\hline $28: 37$ & Groot & Stop & \\
\hline 29:05 & $\begin{array}{l}\text { The Guardians } \\
\text { arrive }\end{array}$ & Gloomy music & $\mathrm{G}, \mathrm{A} b, \mathrm{G} b$ \\
\hline $29: 27$ & Thor on the table & Infinity stones theme & \\
\hline $29: 57$ & Mantis & Magic theme & $\begin{array}{l}\hat{1}, b \hat{2}, b \hat{6} \\
\text { Mantis mind reading }\end{array}$ \\
\hline $30: 28$ & Mantis waking Thor & Magic theme & $\begin{array}{l}\hat{1}, b \hat{2}, b \hat{6} \\
\text { Mantis waking Thor }\end{array}$ \\
\hline $30: 35$ & Thor breathing & Rhythmic, heartbeat like & \\
\hline $30: 50$ & & Stop & Large section of dialog \\
\hline $33: 15$ & $\begin{array}{l}\text { Discussing the } \\
\text { stones }\end{array}$ & Infinity stones theme & \\
\hline $34: 03$ & & Stop & $\begin{array}{l}\text { No longer discussing the } \\
\text { stones }\end{array}$ \\
\hline $35: 00$ & $\begin{array}{l}\text { Assembling into } \\
\text { teams }\end{array}$ & $\begin{array}{l}\text { Hero's theme variations } \\
\text { Minor third motion } \mathrm{G}, \mathrm{F}, \mathrm{A} b\end{array}$ & \\
\hline $35: 44$ & $\begin{array}{l}\text { Thor, Rocket, Grot } \\
\text { depart }\end{array}$ & Stop & \\
\hline $36: 27$ & Wanda and Vision & Sacrifice theme & $\begin{array}{l}\text { Originated in Captain } \\
\text { America, using now to } \\
\text { symbolize sacrificing } \\
\text { past commitments }\end{array}$ \\
\hline $37: 31$ & $\begin{array}{l}\text { Wanda starts } \\
\text { walking }\end{array}$ & Tension & \\
\hline $37: 44$ & The ship on the TV & Dramatic & \\
\hline
\end{tabular}




\begin{tabular}{|c|c|c|c|}
\hline 38:01 & Vision is stabbed & Action, Hero's theme & $\begin{array}{l}\text { Minor third motion } \\
\mathrm{A} b, \mathrm{G} b, \mathrm{~A} \text { (Avengers) } \\
\text { Downward tritones } \\
\text { motion (Black order) }\end{array}$ \\
\hline $39: 50$ & Fall through the roof & Stop & \\
\hline $40: 15$ & $\begin{array}{l}\text { Proxima Midnight } \\
\text { and Corvus Glaive } \\
\text { come through the } \\
\text { roof }\end{array}$ & Ominous & \\
\hline 40:40 & $\begin{array}{l}\text { Cap catches Proxima } \\
\text { Midnight's staff }\end{array}$ & Avengers theme I & \\
\hline 41:44 & Black order leaves & Stop & \\
\hline 41:48 & $\begin{array}{l}\text { Cap talking to } \\
\text { Vision }\end{array}$ & Continues & \\
\hline $42: 20$ & Gamora's past & Stop & \\
\hline $42: 43$ & Chitauri & Thanos theme I & \\
\hline $43: 42$ & $\begin{array}{l}\text { Thanos talking to } \\
\text { Gamora }\end{array}$ & High strings & $\begin{array}{l}\text { The beauty in the string } \\
\text { represent how Thanos } \\
\text { believe he's just }\end{array}$ \\
\hline $44: 29$ & Present Gamora & Stop & Dialog \\
\hline $45: 11$ & "Kill me" & Creates tension & \\
\hline $46: 24$ & Drax & Stop & $\begin{array}{l}\text { Added silence to make } \\
\text { the moment more } \\
\text { awkward }\end{array}$ \\
\hline 47:06 & $\begin{array}{l}\text { Arriving at } \\
\text { Knowhere }\end{array}$ & Dramatic, building tension & \\
\hline 48:00 & Drax walking & Stop & \\
\hline 48:11 & $\begin{array}{l}\text { Thanos stepping on } \\
\text { the Collector }\end{array}$ & Magic theme & $\begin{array}{l}\hat{1}, \hat{2}, b \hat{6} \\
\text { Alerting the viewer, this } \\
\text { isn't real... }\end{array}$ \\
\hline $49: 15$ & $\begin{array}{l}\text { Mantis puts Drax to } \\
\text { sleep }\end{array}$ & Stop & \\
\hline 49:27 & $\begin{array}{l}\text { Thanos throw the } \\
\text { Collector }\end{array}$ & $\begin{array}{l}\text { Low string create tension, } \\
\text { strong chords }\end{array}$ & \\
\hline 50:08 & Thanos falls & Sorrow/remorseful & $\begin{array}{l}\text { Similar to the music } \\
\text { when Loki is killed }\end{array}$ \\
\hline 50:51 & Thanos talks & $\begin{array}{l}\text { Ominous/Thanos theme I and } \\
\text { II }\end{array}$ & \\
\hline $51: 44$ & $\begin{array}{l}\text { Gamora reaches for } \\
\text { her sword }\end{array}$ & Chords on big moments & \\
\hline 52:01 & "let her go" & Sorrowful & \\
\hline $53: 33$ & Bobbles & Stop & \\
\hline $53: 48$ & Thanos leaves & Dramatic & \\
\hline 54:05 & Quinjet & Stop & \\
\hline $54: 43$ & Cap walks in & Avengers theme II & \\
\hline
\end{tabular}




\begin{tabular}{|c|c|c|c|}
\hline 55:34 & $\begin{array}{l}\text { Rhodey closes the } \\
\text { call }\end{array}$ & Stop & Dialog \\
\hline $55: 59$ & Banner & Avengers theme II variation & \\
\hline $56: 25$ & Rhodey & Stop & \\
\hline $57: 04$ & $\begin{array}{l}\text { Vision talking to } \\
\text { Witch }\end{array}$ & $\begin{array}{l}\text { Infinity stone theme } \\
\text { Thanos theme I }\end{array}$ & $\begin{array}{l}\text { Discussing destroying } \\
\text { the mind stone }\end{array}$ \\
\hline $57: 54$ & Banner talking & Music becomes more hopeful & \\
\hline 58:29 & "Find someone fast" & Black Panther theme & \multirow{2}{*}{$\begin{array}{l}\text { Change in music/change } \\
\text { in location }\end{array}$} \\
\hline $59: 35$ & Dr. Strange & Stop & \\
\hline 1:00:12 & $\begin{array}{l}\text { Torturing Dr. } \\
\text { Strange }\end{array}$ & Half step motion & \\
\hline 1:00:40 & & Stop & \\
\hline 1:01:37 & Back to Torturing & Magic theme & $b \hat{2}, \hat{1}, b \hat{6}$ \\
\hline $1: 01: 53$ & Iron Man & $\begin{array}{l}\text { More rhythmic/Avengers } \\
\text { theme }\end{array}$ & \\
\hline $1: 02: 42$ & Ebony Maw & Stop & Dialog \\
\hline 1:04:30 & "we go to him" & Minor third motion $\mathrm{G}, \mathrm{F}, \mathrm{A} b$ & \\
\hline 1:04:54 & Dubbing Spidey & Avengers theme II & $\begin{array}{l}\text { Spidey officially an } \\
\text { Avenger }\end{array}$ \\
\hline 1:05:08 & Thanos's ship & Stop & \\
\hline 1:05:17 & The throne room & Thanos theme I & \\
\hline 1:05:34 & $\begin{array}{l}\text { Thanos offering } \\
\text { food }\end{array}$ & Stop & \\
\hline 1:05:57 & $\begin{array}{l}\text { Thanos justifying } \\
\text { himself }\end{array}$ & $\begin{array}{l}\text { Thanos just motif } \\
\mathrm{A}, \mathrm{Ab}, \mathrm{D} b, \mathrm{~A} b \\
\text { Perfect fourth instead of a } \\
\text { tritone because to Thanos, he } \\
\text { is just }\end{array}$ & $\begin{array}{l}\text { Music starts with } \\
\text { Gamora's view which } \\
\text { contains a tritone (B } b, \mathrm{~A}, \\
\mathrm{E} b, \mathrm{~A}) \\
\text { This theme is a direct } \\
\text { response like Thanos's } \\
\text { words }\end{array}$ \\
\hline 1:07:30 & Thanos walking & Thanos theme I & \\
\hline 1:09:01 & $\begin{array}{l}\text { Thanos using a } \\
\text { stone }\end{array}$ & Magic theme & $\hat{1}, b \hat{2}, b \hat{6}$ \\
\hline 1:09:19 & $\begin{array}{l}\text { Thanos pulling his } \\
\text { arm away }\end{array}$ & Thanos theme I & $\begin{array}{l}\text { Pause for the recording } \\
\text { and dialog }\end{array}$ \\
\hline 1:10:53 & Team Thor & Stop & dialog \\
\hline $1: 13: 23$ & Thor sitting & Hopeful & \\
\hline 1:14:01 & "up my" & Stop & \\
\hline $1: 14: 16$ & Nidavellir & Mysterious & Hollow in texture \\
\hline $1: 15: 32$ & "Stop" & Stop & \\
\hline $1: 16: 37$ & $\begin{array}{l}\text { Eitri describing what } \\
\text { Thanos did }\end{array}$ & Thanos theme I & \\
\hline $1: 16: 47$ & $\begin{array}{l}\text { Thor talking of } \\
\text { killing Thanos }\end{array}$ & Heroic & \\
\hline 1:17:06 & Nebula & Stop & \\
\hline
\end{tabular}




\begin{tabular}{|c|c|c|c|}
\hline 1:17:15 & Nebula's eye & More rhythmic & \\
\hline 1:17:51 & The ship Stark is on & $\begin{array}{l}\text { Tritones } \\
\text { Ending with Minor third } \\
\text { motion } \mathrm{A} b, \mathrm{~Gb}, \mathrm{~A} b, \mathrm{~A}\end{array}$ & The ship is crashing \\
\hline 1:18:51 & Dialog & strings, lighthearted & $\begin{array}{l}\text { Spidey comedy, } \\
\mathrm{A} b, \mathrm{G} b, \mathrm{~A} b, \mathrm{~A}, \mathrm{~A} b, \mathrm{G} b\end{array}$ \\
\hline 1:19:08 & Bomb goes off & Action music & \\
\hline 1:20:03 & "Where Gamora" & Stop & Dialog \\
\hline 1:21:02 & Nidavellir & Dramatic & \\
\hline $1: 21: 29$ & "The Bifrost" & Thor theme & $\mathrm{D}, \mathrm{F}, \mathrm{A}, \mathrm{B} b, \mathrm{~A}$ \\
\hline $1: 21: 51$ & Titan & & Change in location \\
\hline 1:22:07 & Tony looks back & Stop & Dialog \\
\hline $1: 23: 52$ & $\begin{array}{l}\text { Dr. Strange using } \\
\text { the time stone }\end{array}$ & Magic theme & $\hat{1}, \hat{2}, b \hat{6}$ \\
\hline 1:24:13 & Vormir & More rhythmic & \\
\hline 1:25:00 & Red Skull & Mystic and empty & \\
\hline 1:27:17 & Laughing & Stop & \\
\hline $1: 28: 22$ & Thanos turns around & Empty & Percussion \\
\hline $1: 29: 06$ & $\begin{array}{l}\text { Gamora realizing } \\
\text { what is about to } \\
\text { happen }\end{array}$ & Sacrifice theme II & \\
\hline $1: 30: 33$ & $\begin{array}{l}\text { Thanos with the soul } \\
\text { stone }\end{array}$ & Infinity stone theme & \\
\hline 1:31:06 & Team Cap & Avengers theme I & \\
\hline 1:32:00 & "Should we bow" & Stop & \\
\hline $1: 32: 22$ & Bucky & Avengers theme variation & \\
\hline $1: 33: 25$ & Earth's Atmosphere & $\begin{array}{l}\text { Tremolos and glisses } \\
\text { Avengers theme variation } \\
\text { continues }\end{array}$ & Eerie \\
\hline $1: 36: 46$ & Thor jumps & Action music & $\begin{array}{l}\text { Mood changes with } \\
\text { depending on group }\end{array}$ \\
\hline $1: 37: 55$ & Proxima Midnight & Stop & Dialog \\
\hline $1: 38: 16$ & $\begin{array}{l}\text { "you are in } \\
\text { Wakanda" }\end{array}$ & $\begin{array}{l}\text { Minor third motion G, F, Ab, } \\
\text { D, F }\end{array}$ & $\begin{array}{l}\text { This minor third motion } \\
\text { is present in most battles, } \\
\text { Foreshadowing what's to } \\
\text { come? }\end{array}$ \\
\hline $1: 38: 28$ & Pods open & Stop & \\
\hline $1: 38: 50$ & Forest & Stagnant, building tension & \\
\hline $1: 39: 47$ & Shots fired & $\begin{array}{l}\text { Battle music } \\
\text { Rhythmically more active } \\
\text { Minor third motion } \\
\text { Avengers theme variation }\end{array}$ & $\begin{array}{l}\text { Volume decreases for } \\
\text { dialog, pauses for affect, } \\
\text { mood changes when } \\
\text { location changes, but the } \\
\text { main elements of the } \\
\text { music stays the same. } \\
\text { This creates a feeling that }\end{array}$ \\
\hline
\end{tabular}




\begin{tabular}{|c|c|c|c|}
\hline & & & $\begin{array}{l}\text { it is all happening at the } \\
\text { same time }\end{array}$ \\
\hline $1: 44: 32$ & Bucky & Mood is darker & $\begin{array}{l}\text { the tide of battle has } \\
\text { turned }\end{array}$ \\
\hline $1: 45: 18$ & $\begin{array}{l}\text { The Bifrost } \\
\text { opens/Thor arrives }\end{array}$ & Avengers theme II & $\begin{array}{l}\text { The tide of battle has } \\
\text { turned again }\end{array}$ \\
\hline 1:45:56 & $\begin{array}{l}\text { Thanos arrives on } \\
\text { Titan }\end{array}$ & Thanos theme I & \\
\hline 1:47:00 & Reality stone & Thanos just motif & \\
\hline 14808 & Thanos looks up & Battle music & \\
\hline $1: 50: 30$ & $\begin{array}{l}\text { Mantis lands on } \\
\text { Thanos }\end{array}$ & Stop & \\
\hline $1: 51: 28$ & Nebula & Sacrifice theme II & $\begin{array}{l}\text { Thanos morning over } \\
\text { Gamora }\end{array}$ \\
\hline $1: 52: 40$ & $\begin{array}{l}\text { Thanos looks at the } \\
\text { moon }\end{array}$ & Dramatic, large texture & \\
\hline 1:53:03 & Wakanda & Battle music & $\begin{array}{l}\text { Texture, volume change } \\
\text { for dialog }\end{array}$ \\
\hline 1:54:00 & Witch see something & Stop & \\
\hline $1: 54: 25$ & $\begin{array}{l}\text { Witch decides to } \\
\text { join the fight }\end{array}$ & Continues & Same elements \\
\hline $1: 57: 12$ & $\begin{array}{l}\text { Cull Obsidian's } \\
\text { hand }\end{array}$ & Stop & \\
\hline $1: 57: 28$ & Proxima Midnight & Continues & \\
\hline $1: 59: 15$ & $\begin{array}{l}\text { Dr. Strange vs } \\
\text { Thanos }\end{array}$ & $\begin{array}{l}\text { Music changes, more } \\
\text { whimsical }\end{array}$ & $\begin{array}{l}\text { Do to the nature of the } \\
\text { fight...magic vs magic }\end{array}$ \\
\hline 2:00:08 & Iron Man lands & Stop & dialog \\
\hline 2:00:25 & Rockets & Battle music Continues & \\
\hline 2:01:28 & Stark gets stabbed & Stop & \\
\hline $2: 01: 32$ & Tony backing up & Sorrowful, high strings & \\
\hline 2:02:10 & "Stop" & Stop & \\
\hline 2:02:26 & $\begin{array}{l}\text { Dr. Strange giving } \\
\text { up the stone }\end{array}$ & Sacrifice theme & \\
\hline 2:03:13 & Stone in the gauntlet & $\mathrm{Bb}$ minor to $\mathrm{A}$ minor & \\
\hline 2:03:22 & Quin shoots & Battle music Continues & \\
\hline 2:03:32 & "Where is he" & Stop & \\
\hline 2:03:56 & M'Baku/Wakanda & Battle music Continues & \\
\hline 2:04:18 & Witch lands & Stop & $\begin{array}{l}\text { The lack of music creates } \\
\text { an eerie filling, that and } \\
\text { the added sound effects }\end{array}$ \\
\hline 2:05:00 & Thanos & $\begin{array}{l}\text { Menacing chords } \\
\mathrm{G} \text { minor, } \mathrm{E} b \text { minor, } \mathrm{D} \text { minor, } \\
\mathrm{D} b\end{array}$ & $\begin{array}{l}\text { Thanos theme backwards } \\
\mathrm{i}-\mathrm{vi}\end{array}$ \\
\hline 2:05:54 & Vision and Witch & Outline of the Avengers theme & Augmented \\
\hline 2:06:34 & "I just feel you" & Sacrifice theme II & \\
\hline
\end{tabular}




\begin{tabular}{|c|c|c|c|}
\hline $2: 08: 30$ & Mind stone explodes & Stop & \\
\hline $2: 08: 56$ & Thanos looks up & Thanos theme I & \\
\hline $2: 10: 06$ & $\begin{array}{l}\text { Thanos put the stone } \\
\text { in the gauntlet }\end{array}$ & Triumphant fanfare & \\
\hline $2: 10: 16$ & Lighting hits Thanos & lightning theme & $\mathrm{C}, \mathrm{F}, \mathrm{A} b, \mathrm{~A}$ \\
\hline $2: 10: 27$ & Thor lands & Chromaticism & \\
\hline $2: 10: 52$ & & High strings & Proceeds something bad \\
\hline 2:11:09 & The snap & Stop & \\
\hline $2: 11: 44$ & Child Gamora & Spatial/empty texture & $\begin{array}{l}\text { Symbolizing the vastness } \\
\text { of the Soulworld }\end{array}$ \\
\hline $2: 12: 19$ & Wakanda & Stop & \\
\hline $2: 16: 33$ & The Garden & $\begin{array}{l}\text { Triumphant and serene } \\
\text { Motif: G, D, C, E } b \\
\text { Melody is based off the } \\
\text { Avengers theme }\end{array}$ & $\begin{array}{l}\text { Large section of melody } \\
\text { Longest melody ending } \\
\text { with a true cadence, } 4-3 \\
\text { sus Picardy third in } G\end{array}$ \\
\hline $2: 17: 30$ & Credits & $\begin{array}{l}\text { Tells Thanos's journey through } \\
\text { the movie }\end{array}$ & $\begin{array}{l}\text { starts with music similar } \\
\text { to: when he killed Loki, } \\
\text { then Sacrifice theme II, } \\
\text { then the music from the } \\
\text { Garden }\end{array}$ \\
\hline $2: 19: 49$ & Final title screen & Avengers theme II & \\
\hline
\end{tabular}

During Infinity War, Silvestri mostly abandons character themes (with the exception of Thanos) for more large scale themes; he started this idea at the end of the first film. The Avengers endured many challenges (battling Loki, Ultron, and even themselves) that - narratively speaking - the plot is bigger than them as individuals. The only exception is with Thanos. The score for this film is saturated with the Thanos themes because Thanos is the protagonist. Also, everything up to this point has been leading to him. Additionally, Thanos's presence can be felt in almost every moment of this film, whether through his direct actions or through his children. The large-scale themes that Silvestri does focus on (magic, teamwork, and sacrifice), helps the viewers understand the magnitude of the universe, as well as, how connected it is. The use of magic (or extraordinary abilities) speaks to how "trivial" genius-level intellect and super-soldier serum really is in the cosmos. Due to this, individuals have to work together. Thus, individual themes are abandoned for 
a higher use of the Avengers themes. Finally, beyond the size of the universe, all living creatures suffer from similar concepts: starvation, death, pride and (in the case of the score) sacrifice. 


\section{CHAPTER THREE}

\section{The Music of AVENGERS: ENDGAME (2019)}

After the events of Infinity war, the remaining heroes - Iron Man, Captain America, Thor, Hulk, Black Widow, Hawkeye, War Machine, Ant-Man, Rocket Raccoon, Nebula, and Captain Marvel - are scattered across the universe. Each one impacted Thanos's actions differently. However, when presented with a viable plan to reverse the damage, the remaining Avengers and their allies must come together to overcome their defeat.

Typically in superhero films, the hero meets an obstacle or two that they have to rise above to reach their true goal. Infinity war flips this concept and makes the villain the protagonist and the heroes the obstacles. Endgame also deviates from the standard superhero film story arc. Instead of being an antagonist that the heroes must overcome, much of the film is spent overcoming their self-doubt and failure. The heroes do not interact with the "big bad" until two hours into the film. This element in the plot can be heard throughout the score.

The first theme presented is Tony's rest theme; this theme starts with a pedal $G$ and the melody is $\hat{3}, \hat{4}, \hat{1}, \hat{7}, \hat{5}(\mathrm{~B} b, \mathrm{C}, \mathrm{G}, \mathrm{F}, \mathrm{D})$. The second part of the theme is $\hat{5}, \hat{4}, \hat{5}, \hat{6}, \hat{5}, \hat{1}(\mathrm{D}, \mathrm{C}, \mathrm{D}, \mathrm{E} b$, C, D), it occurs while Tony is putting on his jacket. This theme can be heard while Tony is recording a message to Pepper right before he goes to sleep for what he believes to be the last time. This theme is extremely important because the only time it is heard again is after Tony snaps away Thanos and his army. Additionally, the second part of this theme is transposed to G major. This occurs because Tony completed his goal, whereas at the beginning of the film, he felt he was dying in failure. The last theme that pertains to Tony/Iron Man is his motivation theme or his motivation

to correct his failure. This theme is $\mathrm{G}, \mathrm{A}, \mathrm{C}, \mathrm{B} b, \mathrm{E} b, \mathrm{D}$ and can be heard twice, always relating to Peter/Spider-Man, first when Tony looks at a picture of Peter and second when Peter comes back. 
There are several other new themes introduced in this film, one of which is a majestically regal statement in F minor $\hat{1}, \hat{1}, \hat{5}, \hat{5}, \hat{3}, \hat{2}, \hat{7}, \hat{1}$ (F, F, C, C, A $b, \mathrm{G}, \mathrm{E} b, \mathrm{~F})$; this statement signifies the team reuniting. The only other time this theme is represented is when T'Challa, Okoye, and Shuri walk through the portal to aid Captain America. The next new theme presented is the longing theme. This theme is used to convey a character's emotion with dealing with the snap. The full theme can be heard when Natasha is talking to Steve at the Avengers compound. It is in two parts: part one, $\hat{3}, \hat{4}, \hat{3}, \hat{2}, \hat{7}, \hat{1}$ (B $b, \mathrm{C}, \mathrm{B} b, \mathrm{~A}, \mathrm{~F}, \mathrm{G})$ and part two, $\hat{3}, \hat{2}, \hat{1}, \hat{7}, \hat{3}, \hat{2}$ (B $b, \mathrm{~A}, \mathrm{G}, \mathrm{F}, \mathrm{B} b, \mathrm{~A})$. This theme can be heard throughout the film. It is often partial or varied and occurs several times like $\hat{1}, \hat{2}, \hat{3}, \hat{2}, \hat{7}, \hat{1}$ which is the $\hat{3}, \hat{2}, \hat{1}$ in retrograde from part two and the $\hat{2}, \hat{7}, \hat{1}$ from part one combined.

When understanding the plot of the film (overcoming self-doubt and failure), there are a few musical elements that help the viewers to understand the struggles of the characters. One of these elements is the confusion motif, $\hat{5}, \hat{1}, \hat{5}$, followed by a tritone. This theme is heard when the viewers see the Avengers who are having the hardest time dealing with their new reality, Thor and Hawkeye. Thor is suffering from PTSD and has lost himself. The theme, in G minor, is heard after Professor Hulk mentions the name, Thanos. Another instance of the music showing brokenness is when Rocket is trying to get Thor to be himself. After crying Thor says he can do it, however, the music tells a different story. The viewers are presented with a fragmented Thor theme which shows he is not ready. Shortly after, he leaves Rocket. Hawkeye completely changes his identity (becoming Ronin) to deal with losing his family. The character confusion can be heard when Natasha approaches him in Tokyo; the viewers hear the confusion motif in $\mathrm{D} b$ minor.

When Tony is awoken from his sleep, the two pitches that are heard in the beginning are $\mathrm{G}$ to F. This minor seventh is the first two notes of the Captain Marvel theme. The whole theme - 
in $\mathrm{C} \hat{1}, b \hat{7}, \hat{b}, b \hat{7}, \hat{1}, \hat{6}, \hat{5}(\mathrm{C}, \mathrm{B} b, \mathrm{~A}, \mathrm{~B} b, \mathrm{C}, \mathrm{A}, \mathrm{G})$ - can be heard when she destroys The Sanctuary 2. Another character theme reintroduced in this film is Ant-Man's theme. This theme can be heard when Ant-Man comes out of the quantum realm, the theme is augmented in the strings. Black Widows theme is also reintroduced, with the same treatment as Loki's theme in Infinity War. The presentation of this theme feels final.

The treatment of Thanos's themes are somewhat unique. There are two themes pertaining to Thanos at the beginning of the film (the one from the original timeline). These themes are Thanos theme I and the garden theme. However, both of these themes have been altered, so Thanos theme $\mathrm{I}$ is now $\mathrm{G}$ minor to $\mathrm{B} b$ instead of $\mathrm{E} b$ minor to $\mathrm{G}$ minor. This change is attributed to the fact that this Thanos has lost his menacing presence. The second change is in the garden theme; much of the music is the same except the ending stays in minor - this ending is not pleasant for Thanos. When the Thanos from the past is introduced, however, his theme returns the dramatic $\mathrm{E} b$ minor to $\mathrm{G}$ minor. 
Table 3. Cue Sheet for AVENGERS: ENDGAME (2019)

Composer: Alan Silvestri

Director: Russo Brothers

\begin{tabular}{|c|c|c|c|}
\hline Timing & Visual Cue & Music & Notes \\
\hline $2: 00$ & Comic strip & "Dear Mr. Fantasy" by Traffic & Diegetic music \\
\hline $3: 25$ & Iron Man's helmet & Stop & \\
\hline $3: 36$ & Tony recording & $\begin{array}{l}\text { Tony's rest theme } \\
\text { Peddle } G \\
\hat{3}, \hat{4}, \hat{1}, \hat{7}, \hat{5}\end{array}$ & $\mathrm{~B} b, \mathrm{C}, \mathrm{G}, \mathrm{F}, \mathrm{D}$ \\
\hline 5:50 & $\begin{array}{l}\text { Tony putting on his } \\
\text { jacket }\end{array}$ & $\begin{array}{l}\text { Tony's rest theme II } \\
\hat{5}, \hat{4}, \hat{5}, \hat{6}, \hat{5}, \hat{1}\end{array}$ & $\mathrm{D}, \mathrm{C}, \mathrm{D}, \mathrm{E} b, \mathrm{C}, \mathrm{D}$ \\
\hline $7: 13$ & Tony falls asleep & Stop & \\
\hline 8:02 & Captain Marvel & First 2 note from the her theme & G, F \\
\hline 8:05 & Cap & Stop & \\
\hline $8: 23$ & $\begin{array}{l}\text { Captain Marvel } \\
\text { caring The Benatar }\end{array}$ & $\begin{array}{l}\text { Majestic/regal } \\
\mathrm{F}, \mathrm{F}, \mathrm{C}, \mathrm{C}, \mathrm{A} b, \mathrm{G}, \mathrm{E} b, \mathrm{~F}\end{array}$ & $\begin{array}{l}\text { Signals the team is back } \\
\text { together }\end{array}$ \\
\hline 9:00 & Cap and Stark & Sorrowful & $\begin{array}{l}\text { hint of joy in the solo } \\
\text { interludes }\end{array}$ \\
\hline 10:07 & "where is he now" & Stop & \\
\hline 12:06 & $\begin{array}{l}\text { Tony puts the nano } \\
\text { casing in Cap's hand }\end{array}$ & dramatic & Minor thirds B, C, Eb \\
\hline $12: 31$ & "when I get back" & Rhythmically driven & $\begin{array}{l}\text { Melody based in thirds } \\
\text { Harmony ascending, } \\
\text { building the moment }\end{array}$ \\
\hline $14: 37$ & $\begin{array}{l}\text { Thor and Captain } \\
\text { Marvel }\end{array}$ & Avengers theme & \\
\hline $14: 59$ & The Benatar & Rhythmically driven & $\begin{array}{l}\mathrm{D}, \mathrm{E} b, \mathrm{C}, \mathrm{D} \text { this } \\
\text { movement from Infinity } \\
\text { war }\end{array}$ \\
\hline $15: 31$ & $\begin{array}{l}\text { Jump out of } \\
\text { hyperspace }\end{array}$ & $\begin{array}{l}\text { Music follows the mood of the } \\
\text { scene }\end{array}$ & $\begin{array}{l}\text { Melodies based on minor } \\
\text { thirds }\end{array}$ \\
\hline 16:18 & The Garden & Stop & \\
\hline $17: 15$ & $\begin{array}{l}\text { Captain Marvel } \\
\text { attacks Thanos }\end{array}$ & $\begin{array}{l}\text { Half steps and Tritones } \mathrm{G}, \mathrm{A} b, \\
\mathrm{D}\end{array}$ & \\
\hline $17: 45$ & Empty Gantlet & $\begin{array}{l}\text { New Thanos theme } \\
\mathrm{G} \text { minor to } \mathrm{B} b\end{array}$ & \\
\hline 19:04 & $\begin{array}{l}\text { Thor cuts off } \\
\text { Thanos's head }\end{array}$ & Stop & \\
\hline 19:19 & "I went for the head" & The Garden theme & Without the Picardy third \\
\hline 19:54 & Black screen & Stop & \\
\hline
\end{tabular}




\begin{tabular}{|c|c|c|c|}
\hline $21: 17$ & $\begin{array}{l}\text { Steve shaking his } \\
\text { head }\end{array}$ & Sad but hopeful & $\begin{array}{l}\text { Fits the mood of the } \\
\text { speech }\end{array}$ \\
\hline $22: 08$ & San Francisco & High strings & Change \\
\hline $22: 35$ & A rat & Stop & \\
\hline 23:00 & $\begin{array}{l}\text { Ant-man take off his } \\
\text { helmet }\end{array}$ & $\begin{array}{l}\text { Ant-man theme augmented in } \\
\text { the string }\end{array}$ & $\begin{array}{l}\text { theme originated in Ant- } \\
\text { man, Christophe Beck }\end{array}$ \\
\hline $23: 45$ & Scott Lang & Stop & New location \\
\hline $24: 18$ & Memorial park & Gloomy, eerie & $\begin{array}{l}\text { Glisses and half step } \\
\text { movement }\end{array}$ \\
\hline $24: 54$ & & More rhythmically active & "visual painting" \\
\hline $25: 33$ & Casey & Piano and solo viola, longing & \\
\hline $26: 15$ & Avengers compound & Strings & Sense of hope/symbol \\
\hline $26: 28$ & $\begin{array}{l}\text { Peanut butter } \\
\text { sammie }\end{array}$ & Stop & Long section of dialog \\
\hline $29: 42$ & Natasha & Longing theme & $\begin{array}{l}\mathrm{B} b, \mathrm{C}, \mathrm{B} b, \mathrm{~A}, \mathrm{~F}, \mathrm{G} \\
\mathrm{B} b, \mathrm{~A}, \mathrm{G}, \mathrm{F}, \mathrm{B} b, \mathrm{~A}\end{array}$ \\
\hline $30: 38$ & $\begin{array}{l}\text { Scott Lang on } \\
\text { camera }\end{array}$ & $\mathrm{G}, \mathrm{F} \#, \mathrm{~A}$ & \\
\hline $30: 56$ & $\begin{array}{l}\text { Scott Lang inside the } \\
\text { compound }\end{array}$ & Rhythmically more active & \\
\hline $32: 33$ & $\begin{array}{l}\text { "yeah a time } \\
\text { machine" }\end{array}$ & Stop & \\
\hline $33: 19$ & Morgan Stark & Solo clarinet & \\
\hline $34: 02$ & Cap looks at Tony & Avengers theme & \\
\hline $34: 20$ & Tony starts talking & Stop & \\
\hline $36: 14$ & Tony stands up & Strings & \\
\hline $36: 48$ & Cap looks left & $\begin{array}{l}\text { Based the Avengers theme } \\
\text { C, B } b, \mathrm{C}, \mathrm{D}, \mathrm{C}, \mathrm{D}, \mathrm{E} b\end{array}$ & About to change location \\
\hline $36: 54$ & Professor Hulk & Stop & \\
\hline $39: 22$ & $\begin{array}{l}\text { Picture of Tony and } \\
\text { Peter }\end{array}$ & Tony's motivation & $\mathrm{G}, \mathrm{A}, \mathrm{C}, \mathrm{B} b, \mathrm{E} b, \mathrm{D}$ \\
\hline 40:07 & Tony sits down & Avengers theme & \\
\hline $40: 17$ & Morgan Stark & $\begin{array}{l}\text { In G major } \\
\text { Harps and piano }\end{array}$ & $\begin{array}{l}\text { Sounds similar to a toy } \\
\text { box/representing } \\
\text { innocence }\end{array}$ \\
\hline $40: 52$ & $\begin{array}{l}\text { Tony finishes the } \\
\text { juice pop }\end{array}$ & Stop & \\
\hline $42: 08$ & "what" & Longing theme varied & augmented \\
\hline 43:17 & Avengers compound & Stop & \\
\hline $43: 22$ & $\begin{array}{l}\text { Scott open the van } \\
\text { doors }\end{array}$ & Avengers theme variation & \\
\hline $44: 57$ & $\begin{array}{l}\text { Scott comes through } \\
\text { the portal }\end{array}$ & Stop & \\
\hline 47:01 & $\begin{array}{l}\text { Cap and tony shake } \\
\text { hands }\end{array}$ & $\begin{array}{l}\text { Longing varied } \\
\hat{1}, \hat{2}, \hat{3}, \hat{2}, \hat{7}, \hat{1}\end{array}$ & E, F\#, G, F\#, D, E \\
\hline
\end{tabular}




\begin{tabular}{|c|c|c|c|}
\hline 47:17 & Cap's shield & Cap theme & \\
\hline $47: 57$ & taco & Stop & \\
\hline 48:31 & Hulk & $\begin{array}{l}\text { "Supersonic Rocket Ship" by } \\
\text { The Kinks }\end{array}$ & Non-diegetic music \\
\hline $49: 24$ & New Asgard & Stop & \\
\hline $51: 58$ & "Like Thanos" & $\begin{array}{l}\text { Confusion theme } \\
\hat{5}, \hat{1}, \hat{5} \text {, followed by a tritone }\end{array}$ & $\begin{array}{l}\text { In } \mathrm{G} \text { minor } \mathrm{D}, \mathrm{G}, \mathrm{D}, \mathrm{D} \text {, } \\
\mathrm{C}, \mathrm{E} b, \mathrm{E}, \mathrm{B} b, \mathrm{~A}, \mathrm{~A}, \mathrm{G} \\
\mathrm{E}, \mathrm{B} b \text { tritone }\end{array}$ \\
\hline $54: 11$ & Thor drinks & Stop & \\
\hline $54: 18$ & Tokyo & Rhythmic, tension full & Chromatic glisses \\
\hline $56: 23$ & Natasha & Confusion theme & $\begin{array}{l}\text { In } \mathrm{D} b \text { minor } \mathrm{A} b, \mathrm{D} b, \mathrm{~A} b \\
\mathrm{G} b, \mathrm{D}, \mathrm{A} b \\
\mathrm{D}, \mathrm{A} b \text { tritone }\end{array}$ \\
\hline $57: 32$ & $\begin{array}{l}\text { Natasha and Barton } \\
\text { hold hands }\end{array}$ & $\begin{array}{l}\text { "Doom and gloom" by The } \\
\text { Rolling Stones }\end{array}$ & $\begin{array}{l}\text { diegetic music } \\
\text { Gets quieter because the } \\
\text { camera leave the room }\end{array}$ \\
\hline $58: 12$ & "Claim down" & Stop & dialog \\
\hline 1:00:10 & Barton stands up & Joyful tone & $\begin{array}{l}\text { He feel hope after not } \\
\text { seeing his family }\end{array}$ \\
\hline $1: 01: 12$ & Barton shrinks & Stop & \\
\hline 1:01:39 & $\begin{array}{l}\text { Barton shakes his } \\
\text { head }\end{array}$ & Avengers theme I & \\
\hline 1:02:34 & Thor & Stop & \\
\hline 1:02:40 & Thor talking & $\begin{array}{l}\text { Jazz/infinity stone theme/ } \\
\text { Avengers theme }\end{array}$ & \multirow{6}{*}{$\begin{array}{l}\text { Feel of the music } \\
\text { changes with each person } \\
\text { talking }\end{array}$} \\
\hline 1:04:00 & Rocket talking & Avengers theme II & \\
\hline 1:04:20 & Nebula talking & Darker, low strings & \\
\hline 1:04:42 & Natasha, Stark, Hulk & Jazz/Avengers theme II & \\
\hline 1:05:08 & Cap talking & Avengers theme I & \\
\hline 1:06:42 & $\begin{array}{l}\text { Overview of the } \\
\text { team }\end{array}$ & Avengers theme II & \\
\hline 1:07:02 & Team shrinks & Stop & \\
\hline 1:07:09 & New York & $\begin{array}{l}\text { Battle music } \\
\text { heavy brass, rhythmic }\end{array}$ & Similar to the $1^{\text {st }}$ film \\
\hline 1:07:30 & Team arrives & Stop & dialog \\
\hline 1:08:13 & Chitauri & Heroic and triumphant & \\
\hline $1: 08: 32$ & The Ancient One & Dr. Strange theme & $\begin{array}{l}\text { Instrumentation not } \\
\text { melody }\end{array}$ \\
\hline 1:09:13 & Asgard & More active & Location change \\
\hline 1:09:19 & Loki & $\begin{array}{l}\text { Outline of the Thor theme } \\
\hat{5}, \hat{1}, \hat{6}, \hat{5} \text { in minor } \\
\mathrm{F}, \mathrm{B} b, \mathrm{~F} \#, \mathrm{~F}\end{array}$ & $\begin{array}{l}\text { Original theme } \\
\hat{1}, \hat{3}, \hat{5}, \hat{6}, \hat{5} \text { in minor }\end{array}$ \\
\hline $1: 09: 32$ & Jane Foster & Stop & \\
\hline 1:09:59 & Door opens & $\begin{array}{l}\text { Slow fiddle then } \\
\text { Longing varied }\end{array}$ & $\begin{array}{l}\hat{1}, \hat{2}, \hat{3}, \hat{2}, \hat{7}, \hat{1} \\
\mathrm{G}, \mathrm{A}, \mathrm{B} b, \mathrm{~A}, \mathrm{~F}, \mathrm{G}\end{array}$ \\
\hline
\end{tabular}




\begin{tabular}{|c|c|c|c|}
\hline 1:11:19 & Thor crying & Stop & \\
\hline $1: 11: 30$ & Thor stops crying & Fragmented Thor theme & $\begin{array}{l}\text { Low strings } \hat{7}, \hat{1} \\
\text { High strings } \hat{1}, \widehat{3}, \hat{2}, \hat{1}\end{array}$ \\
\hline $1: 11: 52$ & Morad & Avengers theme varied & \\
\hline 1:12:08 & $\begin{array}{l}\text { Widow and } \\
\text { Hawkeye }\end{array}$ & Stop & \\
\hline $1: 12: 18$ & $\begin{array}{l}\text { Widow hugs War } \\
\text { Machine }\end{array}$ & $\begin{array}{l}\text { Nat } \hat{1}, \hat{2}, \hat{4} \text { important? } \\
\text { Barton } \hat{1}, \hat{2}, \hat{3}\end{array}$ & $\begin{array}{l}\text { Thor leave (previous } \\
\text { scene) } \hat{1}, \hat{2}, \hat{5}\end{array}$ \\
\hline $1: 12: 55$ & $\begin{array}{l}\text { War Machine and } \\
\text { Nebula }\end{array}$ & More rhythmic & \\
\hline 1:13:27 & Nebula fighting & $\begin{array}{l}\text { Similar to Thanos theme II, } \\
\text { softer treatment of the Tritone }\end{array}$ & $\begin{array}{l}3,2,1,5,1, \# 1 \\
\mathrm{~B} b, \mathrm{~A}, \mathrm{G}, \mathrm{D}, \mathrm{G}, \mathrm{G} \#\end{array}$ \\
\hline 1:14:14 & $\begin{array}{l}\text { One of Thanos's } \\
\text { ships }\end{array}$ & Stop & \\
\hline $1: 14: 31$ & Transport opens & Thanos theme & Tritones \\
\hline $1: 15: 58$ & Stark Tower & Upbeat/heroic & \\
\hline $1: 16: 15$ & Tony & Avengers theme & \\
\hline $1: 16: 42$ & Hydra agents & Darker tone & \\
\hline 1:16:50 & Loki's scepter & Infinity stone theme & \multirow{2}{*}{$\begin{array}{l}\text { Percussion adds a sense } \\
\text { of tension }\end{array}$} \\
\hline 1:17:30 & Ant-Man & Avengers theme & \\
\hline 1:18:10 & Hydra agents & Infinity stone theme & \\
\hline 1:19:11 & $\begin{array}{l}\text { Cap walks off the } \\
\text { elevator }\end{array}$ & Militarists & \\
\hline $1: 19: 27$ & Thor & $\begin{array}{l}\text { Playful Avengers theme } \\
\text { Pizzicato strings }\end{array}$ & $\begin{array}{l}\text { Fragmentation } \\
\text { "visual painting" Ant- } \\
\text { Man fall with downward } \\
\text { glis }\end{array}$ \\
\hline $1: 19: 56$ & Walking & Militarists & \\
\hline $1: 21: 23$ & $\begin{array}{l}\text { Loki walks through } \\
\text { the portal }\end{array}$ & Stop & \\
\hline $1: 21: 59$ & Cap sees Cap & $\begin{array}{l}\text { Cap theme/Battle music from } \\
\text { Avengers }\end{array}$ & \\
\hline $1: 23: 35$ & $\begin{array}{l}\text { Banner and The } \\
\text { Ancient One }\end{array}$ & Stop & \\
\hline $1: 23: 51$ & $\begin{array}{l}\text { The Ancient One } \\
\text { draws a time line }\end{array}$ & $\begin{array}{l}\text { Music fits the flow on the } \\
\text { conversation }\end{array}$ & \\
\hline $1: 24: 48$ & The Ancient One sits & Stop & \\
\hline $1: 25: 06$ & "Dr. Strange" & Dr. Strange theme & \\
\hline $1: 26: 20$ & Sanctuary 2 & Thanos theme & \\
\hline $1: 28: 20$ & Freya & Tritones & G, G\#, D \\
\hline $1: 28: 43$ & Thor yells & Stop & \\
\hline $1: 29: 12$ & $\begin{array}{l}\text { Freya rub Thor's } \\
\text { head }\end{array}$ & $\begin{array}{l}\text { Soft ascending strings } \\
\text { Slow fiddle }\end{array}$ & Hopeful moment \\
\hline 1:31:00 & Rocket running & More rhythmic & \\
\hline
\end{tabular}




\begin{tabular}{|c|c|c|c|}
\hline $1: 31: 51$ & Thor call Mjölnir & Stop & \\
\hline 1:32:04 & Rocket & $\begin{array}{l}\text { "Come and Get Your Love" by } \\
\text { Redbone }\end{array}$ & $\begin{array}{l}\text { Diegetic music, precedes } \\
\text { a location change }\end{array}$ \\
\hline $1: 32: 52$ & "so he's an idiot" & Stop & \\
\hline 1:33:05 & $\begin{array}{l}\text { Nebula grabs the } \\
\text { tool }\end{array}$ & $\begin{array}{l}\text { Repeated interval } \\
\hat{6}, \hat{5}, \hat{3}, \hat{1}\end{array}$ & $\begin{array}{l}\text { Creates tension and } \\
\text { suspense }\end{array}$ \\
\hline $1: 34: 34$ & Nebula's memories & Thanos theme & \\
\hline $1: 36: 28$ & Nebula running & Rhythmically active & \\
\hline 1:36:56 & Cap & Stop & dialog \\
\hline $1: 37: 35$ & Tony has a though & Infinity stone theme varied & \\
\hline $1: 38: 50$ & Ant-man alone & $\begin{array}{l}\text { "Hey Lawdy Mama" by } \\
\text { Steppenwolf }\end{array}$ & $\begin{array}{l}\text { Diegetic music, precedes } \\
\text { a location change }\end{array}$ \\
\hline 1:39:16 & An office & Stop & \\
\hline 1:39:41 & Elevator & Building tension & \\
\hline 1:40:09 & Tony running & $\begin{array}{l}\text { Infinity stone theme/Avengers } \\
\text { theme }\end{array}$ & \\
\hline $1: 40: 47$ & Case closed & Jazzy/Avengers theme II & \\
\hline $1: 42: 53$ & The Starks & Stop & \\
\hline 1:43:36 & Cap & Avengers theme I & \\
\hline 1:43:59 & Cap sees a picture & Sacrifice theme varied & $\begin{array}{l}\text { theme from The First } \\
\text { Avenger }\end{array}$ \\
\hline 1:44:53 & The Starks & Hopeful & \\
\hline 1:46:32 & Sanctuary 2 & Stop & \\
\hline $1: 47: 25$ & Nebula pull a knife & Ominous music & \\
\hline 1:47:55 & Thanos & Thanos theme & \\
\hline 1:48:15 & Vormir & Avengers theme II & \\
\hline 1:48:41 & Red Skull & Eeriness & Tremolos \\
\hline 1:50:02 & Hawkeye waves & Stop & dialog \\
\hline $1: 51: 15$ & "get right here" & Sacrifice theme II & \\
\hline 1:54:00 & Black screen & Stop & \\
\hline 1:54:11 & Hawkeye & Infinity stone theme & \\
\hline 1:55:00 & Team growing & Stop & \\
\hline $1: 55: 28$ & Close-up on hulk & Black Widow theme & $\begin{array}{l}\text { theme introduced in } \\
\text { Avengers }\end{array}$ \\
\hline 1:55:47 & The dock & Longing theme & Solemn slightly empty \\
\hline $1: 57: 41$ & Stones in the gantlet & Stop & \\
\hline 1:58:46 & Hulk & $\begin{array}{l}\text { Low voices (string, brass, } \\
\text { timpani) }\end{array}$ & $\begin{array}{l}\text { Tritones } \\
\mathrm{B} b, \mathrm{~A}, \mathrm{E} b, \mathrm{~A}, \mathrm{G}, \mathrm{A}, \mathrm{B} b\end{array}$ \\
\hline 1:59:17 & Nebula & Avengers theme varied & \\
\hline $2: 01: 19$ & The snap & Stop & \\
\hline 2:01:43 & Ant-Man's back & Relief & $\begin{array}{l}\text { In G Major } \\
\hat{1}, \hat{5}, \hat{4}, \hat{3}, \hat{7}, \hat{1}\end{array}$ \\
\hline $2: 02: 33$ & Explosion & Stop & \\
\hline
\end{tabular}




\begin{tabular}{|c|c|c|c|}
\hline 2:02:53 & Zoom in & Action music & $\begin{array}{l}\text { Small intervals creating } \\
\text { tension, held pitches and } \\
\text { silence compounds the } \\
\text { tension at critical } \\
\text { moments }\end{array}$ \\
\hline 2:04:54 & Sanctuary 2 & Thanos theme & \\
\hline $2: 05: 49$ & Gamora and Nebula & Hopeful & \\
\hline $2: 06: 38$ & Iron Man walking & Stop & \\
\hline $2: 07: 00$ & The big three & Slightly empty, intruding solos & Creates a sense of unease \\
\hline 2:09:29 & Fight starts & $\begin{array}{l}\text { Action music } \\
\text { Highly rhythmic }\end{array}$ & $\begin{array}{l}\text { held pitches and silence } \\
\text { compounds the tension at } \\
\text { critical moments }\end{array}$ \\
\hline $2: 12: 57$ & Cap welding Mjölnir & Cap theme & \\
\hline $2: 14: 19$ & Cap beaten & Thanos theme & \\
\hline 2:15:00 & Transporter opens & $\begin{array}{l}\text { Thanos theme II augmented } \\
\mathrm{D}, \mathrm{A} b, \mathrm{D}, \mathrm{B} b, \mathrm{D}, \mathrm{B}\end{array}$ & $\begin{array}{l}\text { Second half of the } \\
\text { Thanos theme II without } \\
\text { the } \mathrm{E} b \text { so there is a } \\
\text { tritone (Thanos is } \\
\text { differently the bad guy) }\end{array}$ \\
\hline $2: 15: 28$ & Thanos & Thanos theme I & \\
\hline 2:15:39 & Cap pulls the strap & Hopeful, horn solo & $\begin{array}{l}\text { Solo because he standing } \\
\text { alone }\end{array}$ \\
\hline $2: 16: 01$ & Cap stops & Stop & \\
\hline $2: 16: 19$ & Cap looks back & $\begin{array}{l}\text { Majestic/regal } \\
\mathrm{G}, \mathrm{G}, \mathrm{D}, \mathrm{D}, \mathrm{B} b, \mathrm{~A}, \mathrm{~F}, \mathrm{G}\end{array}$ & $\begin{array}{l}\text { Signals the team is back } \\
\text { together }\end{array}$ \\
\hline $2: 17: 58$ & Everyone & Full Avengers theme & \\
\hline $2: 19: 34$ & $\begin{array}{l}\text { Giant-Man steps on } \\
\text { Cull Obsidian }\end{array}$ & Stop & Dialog \\
\hline $2: 19: 43$ & Parker and Tony & Tony's motivation & $\mathrm{G}, \mathrm{A}, \mathrm{C}, \mathrm{B} b, \mathrm{E} b, \mathrm{D}$ \\
\hline $2: 19: 58$ & Starlord & Action music & \\
\hline $2: 20: 15$ & Gamora & Dramatic & \\
\hline $2: 20: 39$ & Second knee & Stop & \\
\hline $2: 20: 55$ & Hawkeye & $\begin{array}{l}\text { Action music } \\
\text { Elements Avengers theme }\end{array}$ & $\begin{array}{l}\text { Similar to the music from } \\
\text { the Wakanda fight scene } \\
\text { in Infinity War }\end{array}$ \\
\hline $2: 21: 21$ & Giant-Man shrinks & $\begin{array}{l}\text { Action music, } \\
\text { Elements of Thanos theme, } \\
\text { Ascending lines creating more t } \\
\text { held pitches and silence }\end{array}$ & $\begin{array}{l}\text { Upbeat and rhythmic, } \\
\text { Use of tritones, } \\
\text { ension within the scene, }\end{array}$ \\
\hline $2: 25: 37$ & $\begin{array}{l}\text { Rocket jumps on } \\
\text { Groot }\end{array}$ & Stop & \\
\hline $2: 25: 58$ & Captain Marvel & $\begin{array}{l}\text { Captain Marvel theme } \\
\text { In } C: \hat{1}, b \hat{7}, \hat{6}, b \hat{7}, \hat{1}, \hat{6}, \hat{5}\end{array}$ & $\begin{array}{l}\text { Introduced in Captain } \\
\text { Marvel } \\
\mathrm{C}, \mathrm{B} b, \mathrm{~A}, \mathrm{~B} b, \mathrm{C}, \mathrm{A}, \mathrm{G}\end{array}$ \\
\hline $2: 26: 28$ & Thanos & Action music & Silence for the dialog \\
\hline
\end{tabular}




\begin{tabular}{|c|c|c|c|}
\hline $2: 27: 57$ & Explosion & Stop & \\
\hline $2: 28: 02$ & Iron Man & \multicolumn{2}{|c|}{$\begin{array}{l}\text { Action music without the rhythmic attention, } \\
\text { Thanos theme, glisses, tremolos, melodic motion in minor } \\
\text { thirds }\end{array}$} \\
\hline $2: 29: 51$ & The snap & Stop & \\
\hline $2: 30: 32$ & Dusting & $\begin{array}{l}\text { Endgame theme } \\
\hat{1}, \widehat{3}, \widehat{5}, \widehat{7}, \widehat{7}, \widehat{5}, \widehat{6}, \widehat{6}, \hat{4}, \hat{5} \\
\hat{3}, \hat{2}, \hat{2}, \widehat{5}, \hat{5}, \hat{7}, \widehat{5}, \widehat{6}, \widehat{6}, \widehat{4}, \hat{5}\end{array}$ & $\begin{array}{l}\text { Same music on the title } \\
\text { menu } \\
\text { G, B } b, \mathrm{D}, \mathrm{F}, \mathrm{F}, \mathrm{D}, \mathrm{E}, \mathrm{E}, \\
\mathrm{C}, \mathrm{D} \\
\mathrm{B} b, \mathrm{~A}, \mathrm{~A}, \mathrm{D}, \mathrm{D}, \mathrm{F} \mathrm{D}, \mathrm{E}, \\
\mathrm{E}, \mathrm{C}, \mathrm{D}\end{array}$ \\
\hline $2: 31: 21$ & Thanos walking & Thanos theme & \\
\hline $2: 31: 40$ & Thanos dusting & Stop & \\
\hline $2: 32: 14$ & Rhodey and Tony & $\begin{array}{l}\text { Tony's rest theme } \\
\text { Peddle } G \\
\widehat{3}, \hat{4}, \hat{1}, \hat{7}, \hat{5}\end{array}$ & $\mathrm{~B} b, \mathrm{C}, \mathrm{G}, \mathrm{F}, \mathrm{D}$ \\
\hline $2: 33: 50$ & Light goes off & Stop & \\
\hline $2: 34: 24$ & Pepper cries & $\begin{array}{l}\text { Tony's rest theme II } \\
\text { In } G \text { major } \\
\hat{3}, \widehat{2}, \widehat{3}, \widehat{4}, \widehat{2}, \widehat{3} \\
\text { Hopeful resolution }\end{array}$ & $\begin{array}{l}\text { Orchestration thins for } \\
\text { dialog }\end{array}$ \\
\hline $2: 40: 15$ & Thor & Stop & dialog \\
\hline $2: 42: 57$ & Infinity Stones & Solemn & \\
\hline $2: 43: 26$ & Sam starts talking & Cap theme & \\
\hline $2: 43: 57$ & Cap turns around & More rhythmic & \\
\hline $2: 44: 36$ & $\begin{array}{l}\text { Hulk grads the } \\
\text { screen }\end{array}$ & Stop & \\
\hline $2: 45: 03$ & Bucky and Sam & $\begin{array}{l}\text { Builds tension and resoles into } \\
\text { hopefulness }\end{array}$ & \\
\hline $2: 47: 30$ & "Thank you" & New Cap theme & \\
\hline $2: 47: 57$ & Steve looking off & $\begin{array}{l}\text { "It's Been a Long, Long Time" } \\
\text { by Harry James }\end{array}$ & Diegetic music \\
\hline
\end{tabular}

Much like Infinity War, Silvestri did not focus on character themes, however, this film does have more use of character themes. This is due to the amount of characters that need to be introduced into the crossover storyline. ${ }^{16}$ Although these character themes are present, they are not used to progress the sonic narrative. This is supported by the fact that none of the main character

\footnotetext{
${ }^{16} \mathrm{~A}$ crossover is when two or more otherwise individually separate and distinct characters, settings, or universes are combined into a single story.
} 
themes are used in the manner in which they were used in the first film (transforming or combining themes to show character development) - the only exception is the Thor theme at $(1: 11: 30)$. Silvestri instead focuses on larger concepts: self-doubt and confusion; longing for the past (preThanos); and the Avengers. 


\section{CONCLUSION}

Most of the themes and motifs Silvestri presents to viewers serve as "visual cues" meaning there is little to no thematic transformation, ${ }^{17}$ however, the themes serve a different purpose. Like the music surrounding the themes, the music in these three films are meant to help guide the viewers through the films' narrative. The thematic material is more a compass: it reveals when a character has the upper-hand; foreshadows; reinforces emotion; and directs the viewers' attention.

Where these relatively stable thematic universes paper over some of the stark stylistic contrasts between films, the MCU's inconsistency highlights differences in creative direction...the MCU consists of 22 films by 17 directors scored by 14 different composers. Incoming composers seem to feel little pressure to honor pre-existing themes for characters, leading to a lingering sense that composers are continually reinventing the wheel. For example, the three scores for the Iron Man films bear little resemblance to one another, each composer offering their own version of a character theme. ${ }^{18}$

Many believe that the MCU's lack of saturated character musical themes is a missed opportunity.

However, they fail to consider that by changing themes, composers have helped sonically progress the character development. The Iron Man from Iron Man (2008) is a much different man/hero than the Iron Man in Avengers: Endgame (2019). Thus, is it really necessary for the sound of Iron Man to stagnate musically?

Much like the characters themselves, their music evolves to suit their new contexts in Endgame. Alan Silvestri unravels the franchise's most recognizable musical cues to ask a simple question: what happens to a character's music when they grow beyond the ideals that their music once represented? Thanos and Captain America-the moral extremes of the film - typify this musical treatment, as the manipulation of their music signals their evolving characterization and motivations. ${ }^{19}$

\footnotetext{
17 Thematic transformation or metamorphosis is a compositional technique were a theme or motif is varied through rhythmic alteration, augmentation, diminution, and/or fragmentation.

${ }^{18}$ Grace Edgar, "Theme as Easter Egg: Illusions of Organicism in Avengers: Endgame”. Musicology Now. Accessed October 29, 2019. http://www.musicologynow.org/2019/06/theme-as-easter-egg-illusions-of.html?m=1.

${ }^{19}$ Bradley Spiers, “Avengers Disassembled: Music and Unmaking in Endgame”. Musicology Now. Accessed October 29, 2019. http://www.musicologynow.org/2019/06/avengers-disassembled-music-and.html?m=1.
} 
These three Avengers films show that the MCU establish a sonic narrative that spans all the films. However, like the plot and characters of the individual films, the sound evolves. Marvel's The Avengers serves as the foundation of the universe, when almost every character is presented with their own theme and the "sound" of the universe is also established. While most themes are not as "singable" as the 1960's animated Spider-Man series, they are still pronounced and defined..$^{20}$ Most importantly, these themes help to codify the overarching sound of the universe. Avengers: Infinity War continues the sonic world-building by exploring the sound of the universe from another perspective, following the character development of Thanos the Mad Titan, who is the villainous protagonist. The universe is bigger than what was previously portrayed and the soundtrack compounds that fact. The Avengers are no longer a group of individuals, thus individual themes were not as pronounced. The "staple sound" of the Avengers theme also changed, creating an amalgamation of Silvestri's original and Danny Elfman's later rendition in Avengers: Age of Ultron. Notwithstanding, this fits the overall narrative; the team has grown and has improved in its cohesiveness when fighting together. Avengers: Endgame tells the story of how the heroes react to complete and total failure and how they rise above it. The team is broken and consequently, the sound follows. Character themes are fragmented, changed, or abandoned completely. Even the Avengers theme is transformed.

Nevertheless, even throughout all the changes, the overall sound of the universe remains. It is not until Thanos wipes out half of existence at the end of Avengers: Infinity War that the soundscape becomes "broken," but once everyone is brought back, that sound is "corrected" and returns. Through all the change, there were still things that remained "pure," the infinity stones

\footnotetext{
${ }^{20}$ Reza The Rizzler. Spider-Man 1967 TV Show Intro, 2013. Accessed November 10, 2019. https://www.youtube.com/watch?v=xsx3JCw62WQ. Spider-Man was an animated television series that aired from 1967 to 1970 . The theme song was composed by Bob Harris with lyrics by Paul Francis Webster.
} 
and the idea of sacrifice. The infinity stones were always an impending threat that caused massive, devastating destruction. Therefore, the sound of these six entities remained the same. Additionally, the idea of sacrifice is universal. The music's function is the same across each film which creates a universal sonic narrative.

This study is, however, somewhat limited by only analyzing three films; the larger soundscape of the MCU (23 major films to date) is only briefly taken into consideration. Nevertheless, the combination of these three films provided a prime starting point in understanding the soundscape of the MCU. These films carry large scale universal consequences as well as a crossover storyline. Understanding the themes set forth in these films will help to guide future works into the scores of the MCU. 


\section{BIBLIOGRAPHY}

\section{Films}

Avengers: Endgame. DVD. Directed by Joe and Anthony Russo. Burbank, CA: Buena Vista Home Entertainment, 2019.

Avengers: Infinity War. Digital. Directed by Joe and Anthony Russo. Burbank, CA: Buena Vista Home Entertainment, 2018.

Marvel's the Avengers. DVD. Directed by Joss Whedon. Burbank, CA: Buena Vista Home Entertainment, 2012.

\section{Videos}

Bill, Christopher. Marvel Music Analysis: Avengers (2012) by Alan Silvestri - Complete Leitmotif Breakdown, 2019. Accessed October 24, 2019. $\quad$ https://youtu.be/k6ubic0mWUE. . Marvel Music Analysis: Infinity War by Alan Silvestri - Complete Leitmotif Breakdown, 2019. Accessed October 24, 2019. https://youtu.be/epLGQaHox-g.

\section{Books, Articles, and Theses}

Broabbus, William. "Marvel Superhero Film: The Use of Music and Sound Design in Narrative Transition Zones". B.A. Honors Thesis, The Pennsylvania State University, 2016. https://honors.libraries.psu.edu/catalog/29361.

Chambliss, Julian C, William L Svitavsky, and Daniel Fandino, eds. Assembling the Marvel Cinematic Universe: Essays on the Social, Cultural and Geopolitical Domains. Jefferson, N.C.: McFarland \& Company, 2018.

Chion, Michel, and Walter Murch. Audio-Vision: Sound on Screen. Edited by Claudia Gorbman. New York: Columbia University Press, 1994.

Claremont, Chris, and Stan Lee, Tom DeFalco, Peter Sanderson, Tom Brevoort, Michael Teitelbaum, Daniel Wallace, Andrew Darling, Matt Forbeck, Alan Cowsill, Adam Bray. Marvel Encyclopedia. New Edition. American ed. New York: DK Publishing, 2019.

Cooke, Mervyn. A History of Film Music. New York: Cambridge University Press, 2008.

Dougall, Alastair, and Tom DeFalco, Peter Sanderson, Tom Brevoort, Michael Teitelbaum, Daniel Wallace, Andrew Darling, Matt Forbeck. The Marvel Comics Encyclopedia: A Complete Guide to the Characters of the Marvel Universe. Updated and Expanded ed. New York: DK Pub, 2009. 
Edgar, Grace. "Theme as Easter Egg: Illusions of Organicism in Avengers: Endgame". Musicology Now. Accessed October 29, 2019. http://www.musicologynow.org/2019/06/theme-as-easter-egg-illusions-of.html?m=1.

Gilmore, James, and Matthias Stork, eds. Superhero Synergies: Comic Book Characters Go Digital. Lanham, Maryland: Rowman \& Littlefield, 2014. 2014. Accessed September 19, 2019. https://ebookcentral.proquest.com/lib/wvu/detail.action?docID=1648849.

Hill, Andy. Scoring the Screen: The Secret Language of Film Music. Music Pro Guides. Milwaukee, WI: Hal Leonard Books, 2017.

Kaveney, Roz. Superheroes!: Capes and Crusaders in Comics and Films. London: I.B. Tauris, 2008.

Lehman, Frank. "Hollywood Cadences: Music and the Structure of Cinematic Expectation." Music Theory Online, 19, no. 4 (2013). . Hollywood Harmony: Musical Wonder and the Sound of Cinema. New York, NY: Oxford University Press, 2018.

Neumeyer, David. "Film Music Analysis and Pedagogy." Indiana Theory Review 11 (1990): 127. Accessed September 6, 2019. http://www.jstor.org/stable/24045976. . The Oxford Handbook of Film Music Studies. New York: Oxford Music Press, 2014.

Spiers, Bradley. "Avengers Disassembled: Music and Unmaking in Endgame". Musicology Now. Accessed October 29, 2019. http://www.musicologynow.org/2019/06/avengersdisassembled-music-and.html? $\mathrm{m}=1$

Wierzbicki, James Eugene, and Nathan Platte, Colin Roust, eds. The Routledge Film Music Sourcebook. 1st ed. New York: Routledge, 2012.

Winters, Ben. "The Non-Diegetic Fallacy: Film, Music, and Narrative Space." Music \& Letters 91, no. 2 (2010): 224-44. Accessed September 6, 2019. http://www.jstor.org/stable/40871578. 